\title{
AGGREGATION, AUCTIONS, AND OTHER DEVELOPMENTS IN THE SELECTION OF LEAD COUNSEL UNDER THE PSLRA
}

\author{
JILL E. FISCH* \\ I \\ INTRODUCTION
}

The Private Securities Litigation Reform Act of 1995 (the "PSLRA") ${ }^{1}$ reflects an innovative congressional effort to refine securities fraud class actions. In adopting the PSLRA, Congress recognized that although the class action is a valuable tool for increasing plaintiff access to the legal system, its structure presents opportunities for abuse. In particular, collective action problems and small claimant stakes limit plaintiff participation in litigation decisions. Decisions are made by entrepreneurial lawyers who effectively control the litigation. Plaintiffs' lawyers have a substantial interest in the litigation-frequently a larger interest than any individual class member. Lawyer control of class actions coupled with the potential divergence between the interests of the lawyers and those of the class creates a risk that litigation decisions will not reflect the best interests of the plaintiff class or society as a whole.

Although the entrepreneurial lawyer is central to the functioning of the class action, structural problems raise concerns of litigation malfunction. Courts have been unsuccessful in addressing these problems despite their efforts to oversee litigation decisions and their broad control over the conduct of class actions and the award of attorneys' fees. Accordingly, Congress responded by adopting a mechanism in the PSLRA for the appointment of a statutory lead plaintiff. $^{2}$ The statute reflects the expectation that the lead plaintiff, presumptively the investor with the largest financial interest in the litigation, will oversee the conduct of the case and monitor the decisions of class counsel. ${ }^{3}$ This enhanced client monitoring has the potential to reduce agency costs and improve litigation decisions.

Copyright (C) 2001 by Jill E. Fisch

This article is also available at http://www.law.duke.edu/journals/64LCPFisch.

* Professor of Law, Fordham University. I gratefully acknowledge the assistance of Barbara Hart.

1. Pub. L. No. 104-67, 109 Stat. 737 (codified as amended in scattered sections of 15 U.S.C.).

2. See 15 U.S.C. $\$ 78 u-4(a)(3)$ (Supp. IV 1998).

3. See id. $\$ 78 \mathrm{u}-4(\mathrm{a})(3)(\mathrm{B})(\mathrm{iii})(\mathrm{I})$. 
Litigation under the PSLRA has tested the efficacy of the lead plaintiff provision, introducing a number of promising developments. Institutional investors have demonstrated an increasing willingness to seek appointment as lead plaintiff and to play an active role in litigation. In some cases, the participation of institutional investors seems to be having the effects intended by Congress, including active negotiation of fee agreements and quality resolution of lawsuits. In the recent Cendant case, for example, three public pension funds, acting as a lead plaintiff group, oversaw litigation that culminated in the largest securities fraud settlement in history. ${ }^{4}$

Substantial uncertainty remains, however, about the operation of the lead plaintiff provision and the appropriate method for selecting lead counsel. Plaintiffs' firms have developed a variety of techniques to secure lead counsel appointments. Some firms assemble large groups of investors to act as lead plaintiff; other firms are developing ongoing relationships with institutional investors who are likely to be repeat players in securities fraud litigation. Courts have varied in their analyses as to how the lead plaintiff should be selected. Decisional uncertainty, coupled with the high stakes involved in the selection of lead counsel, has led to significant collateral litigation. ${ }^{5}$ This litigation may deter some investors from seeking lead plaintiff status. The issues raised in the battle over selection of lead plaintiff have also caused some courts to claim for themselves the task of selecting lead counsel. Several courts have gone so far as to auction off the lead counsel position. ${ }^{6}$

This article focuses on two of the most problematic developments under the lead plaintiff provision: (1) the use of aggregation to unite large numbers of unrelated investors into a lead plaintiff group; and (2) the appointment of lead counsel through sealed bid auctions conducted by the courts. Both developments weaken the relationship between the statutory lead plaintiff and class counsel. As a result, they reduce the ability of the lead plaintiff to monitor the litigation, potentially frustrating the objectives of the PSLRA.

In Part II, the article briefly reviews the background of selection of counsel issues in class action litigation and Congress's effort to respond to these issues in the PSLRA. Part III examines aggregation, a key issue in the application of the lead plaintiff provision. Although a few recent decisions suggest that aggre-

4. See Cendant Corporation Agrees to Record Payment to Settle Class Financial Fraud Allegations, 31 Sec. Litig. \& Reg. Rep. (BNA) 1618 (Dec. 13, 1999) (describing Cendant settlement).

5. The collateral litigation would likely be more extensive but for the courts' virtually universal conclusion that defendants do not have standing to challenge the appointment of the lead plaintiff. See, e.g., Takeda v. Turbodyne Techs., Inc., 67 F. Supp. 2d 1129, 1138 (C.D. Cal. 1999); Gluck v. Cellstar Corp., 976 F. Supp. 542, 550 (N.D. Tex. 1997); Greebel v. FTP Software, Inc., 939 F. Supp. 57, 60-61 (D. Mass. 1996). But see In re Landry's Seafood Restaurant, Inc. Sec. Litig., No. H-99-1948, 2000 U.S. Dist. LEXIS 7005, at *6-7 (S.D. Tex. Mar. 30, 2000) (holding that defendants lacked standing to challenge appointment of the lead plaintiff, but concluding that the court could consider the same matters sua sponte); Howard Gunty Profit Sharing v. Quantum Corp., No. 96-20711(SW), slip op. at 6-7 (N.D. Cal. Feb. 6, 1997) ("[W]hen ... there are no other potential lead plaintiffs to challenge a moving party, the Court must rely on the defendants to insure that the requirements of [the Reform Act] are satisfied.").

6. See infra note 192. 
gation is doctrinally dead, the vast majority of courts continue to appoint lead plaintiff groups consisting of several unrelated investors. The article considers whether these appointments are appropriate and concludes that they are both impractical and inconsistent with the purpose of the statute. Part IV analyzes lead counsel auctions. Several recent decisions suggest increased judicial willingness to consider auctioning off the role of lead counsel. The article demonstrates that auctions create a variety of unresolved implementation issues. More important, lead counsel auctions improperly allow the court to usurp the role of the lead plaintiff in the selection and retention of lead counsel.

The importance of understanding the relationship of recent case developments to the structure and purpose of the PSLRA cannot be understated. The current process of selecting the lead plaintiff and appointing lead counsel is effectively insulated from appellate review. ${ }^{7}$ In addition to raising significant issues of statutory interpretation and application, the cases reflect a troubling trend: Courts are making an effort to maintain their supervisory role in class action litigation at the expense of the increased client empowerment contemplated by the statute.

\section{II}

\section{BACKGROUND SELECTION OF COUNSEL ISSUES}

\section{A. Selection of Counsel in Securities Class Actions}

Cost and other barriers limit the ability of many potential plaintiffs to use the litigation system to obtain redress. ${ }^{8}$ The modern class action offers one means of addressing this problem. The class action partially overcomes free rider and other collective action problems by allowing groups of small claim plaintiffs to join together for the purpose of suit. ${ }^{9}$ Similarly, the class action allows plaintiffs to share the costs of litigation. Coupled with the contingent fee structure, the class action grants small claimants access to litigation without requiring them to risk costs that are disproportionate to their expected recovery. By permitting cost sharing and reducing risk, the class action provides a tool for increasing access to the legal system. This increased access can result in greater deterrence of corporate misconduct and enhanced victim compensation. ${ }^{10}$

7. See, e.g., Metro Servs. v. Wiggins, 158 F.3d 162, 165 (2d Cir. 1998) (dismissing challenge to lead plaintiff appointment under the collateral order doctrine); 9th Cir. Lifts Stay in Network Associates Lead Plaintiff Dispute, PENSION Fund. LiTIG. REP., Apr. 10, 2000, at 11 (describing the Ninth Circuit's denial of request for mandamus in connection with the trial court's appointments of lead plaintiff and class counsel in Network Associates litigation).

8. See, e.g., NeIl K. Komesar, IMPERfECt Alternatives 124-28 (1994) (describing costs of participation in the adjudicative process).

9. See, e.g., Jonathan R. Macey \& Geoffrey P. Miller, The Plaintiffs' Attorney's Role in Class Action and Derivative Litigation: Economic Analysis and Recommendations for Reform, 58 U. CHI. L. REV. 1, 8 (1991).

10. See, e.g., Jill E. Fisch, Class Action Reform, Qui Tam, and the Role of the Plaintiff, 60 LAW \& CONTEMP. PROBS. 167, 173-76 (Autumn 1997) (describing the role of class actions in deterring corporate misconduct and compensating injured victims). 
The effectiveness of the class action depends to a large degree on its structure. The class action is a representative suit in which individual class members do not participate actively in litigation decisions. The stakes of class members are generally too small to warrant active monitoring. Instead, class actions are effectively run by class counsel. Plaintiffs' lawyers bear most of the risk of the lawsuit and exercise virtually complete control over litigation decisions. ${ }^{11}$

Lawyer-driven litigation is not inherently undesirable. The willingness of plaintiffs' lawyers to investigate potential causes of action, mobilize the plaintiff class, and bear the costs and risks associated with the suit leads to an increase in enforcement and provides a valuable contribution to the deterrence of corporate misconduct. ${ }^{12}$ Indeed, by providing suitable financial incentives for these activities, class actions have led to the evolution of entrepreneurial plaintiffs' lawyers, who play a central role in rendering the class action a meaningful vehicle for compensating victims and deterring wrongful conduct. ${ }^{13}$

The challenge for those seeking to refine the class action is to develop a structure that encourages class counsel to make its litigation decisions out of concern for the interests of the plaintiff class. ${ }^{14}$ The procedures applicable to class actions, for the most part, fail to meet that challenge. Instead, class action procedures increase lawyer control over litigation decisionmaking and, at the same time, increase agency costs by creating perverse incentives for class counsel. ${ }^{15}$

These problems start at the outset of the suit. As Elliott Weiss and John Beckerman have observed ${ }^{16}$ courts most commonly select lead counsel by appointing the lawyer who files the first complaint. ${ }^{17}$ The natural and foreseeable consequence of this approach is the creation of a race to the courthouse. ${ }^{18}$

11. See John C. Coffee, Jr., Understanding the Plaintiff's Attorney: The Implications of Economic Theory for Private Enforcement of Law Through Class and Derivative Actions, 86 COLUM. L. REV. 669, 677-78 (1986).

12. See Fisch, supra note 10, at 175 (describing defense of entrepreneurial class actions as a mechanism for deterring corporate misconduct).

13. See, e.g., John C. Coffee, Jr., The Regulation of Entrepreneurial Litigation: Balancing Fairness and Efficiency in the Large Class Action, 54 U. CHI. L. REV. 877 (1987) (describing economic incentives for entrepreneurial litigation).

14. See Fisch, supra note 10, at 176-83 (describing proposals for class action reform).

15. The literature on class actions and potential class action reform is extensive. See generally Michael E. Solimine \& Christine Oliver Hines, Deciding to Decide: Class Action Certification and Interlocutory Review by the United States Courts of Appeals Under Rule 23(f), 41 WM. \& MARY L. REV. 1531, 1532-34 (2000) (describing and citing scholarly literature on class actions).

16. See Elliott J. Weiss \& John S. Beckerman, Let the Money Do the Monitoring: How Institutional Investors Can Reduce Agency Costs in Securities Class Actions, 104 YALE L.J. 2053, 2062 (1995).

17. No statute or procedural rule gives the courts affirmative authority to select class counsel. The closest thing to an authoritative source on the subject, the Manual for Complex Litigation, indicates that the selection of lead counsel is normally made by the parties or their attorneys and warns that "the court should not, in the absence of extraordinary circumstances, select and appoint lead counsel" itself. Nanette L. Stasko, Comment, Competitive Bidding in the Courthouse: In re Oracle Securities Litigation, 59 BROOK. L. REV. 1667, $1673-74$ n.21 (1994). Nonetheless, dictum in MacAlister v. Guterma, 263 F.2d 65 (2d Cir. 1958), is widely cited for the authority that the court has the power to appoint "lead counsel" in a class action.

18. See Weiss \& Beckerman, supra note 16, at 2062. 
There are at least three problems with this result. First, lawyers are encouraged to file complaints rapidly and defer their investigation of the merits of those complaints until after filing. Second, to file a complaint rapidly, lawyers must seek out prospective plaintiffs rather than waiting to be approached by a disgruntled investor. Finally, class counsel is appointed with little consideration given to qualifications. ${ }^{19}$

Courts create additional problems by vesting class counsel with virtually complete control over litigation decisionmaking. Despite judicial rhetoric about the importance of the class representative, class representatives have no official role in class action decisionmaking. ${ }^{20}$ Courts have upheld the authority of counsel to make such vital decisions as whether to settle a case without requiring that counsel consult with, much less obtain the approval of, the class representative. ${ }^{21}$ Class representatives do not regularly attend court proceedings and settlement conferences. ${ }^{22}$ The class representative does not even have the right to replace class counsel. ${ }^{23}$

Lawyer control over litigation decisions is problematic to the extent that lawyer and client interests diverge. Class members generally would prefer litigation decisions to be made in a manner that maximizes expected recovery. ${ }^{24}$ Counsel has an incentive to make decisions in a manner that maximizes its fee award, even if those decisions do not maximize recovery. The most commonly cited example of the potential conflict between lawyer and client interests is counsel's incentive to agree to a cheap settlement if the agreement provides a generous fee award. As the court explained in the Oracle case:

[w] hen the prospect of settlement arises, the unique dynamics of the lawyer/client relationship in class actions raise particular problems: an attractive attorney fee provision in the settlement agreement may induce class counsel to settle regardless of the likeli-

19. See Conference Report on The Private Securities Litigation Reform Act of 1995, H.R. REP. No. 104-369, at 33 (1995), reprinted in 1995 U.S.C.C.A.N. 730, 732 [hereinafter CONF. REP.] (explaining that race to the courthouse results in courts giving insufficient consideration to the most thoroughly researched but later-filed complaint); see also Weiss \& Beckerman, supra note 16, at 2063 n.47 (exploring the extent to which courts consider reputation in the selection of lead counsel).

20. See Fisch, supra note 10, at 174.

21. The Third Circuit's recent decision in Lazy Oil Co. v. Witco Corp., 166 F.3d 581 (3d Cir. 1999), illustrates the minimal power possessed by the traditional class representative. The court in Lazy Oil approved a settlement proposed by class counsel over the objections of three of the four named class representatives, despite the fact that the class representatives were sophisticated parties, and despite the agreement of an additional 384 class members. See John C. Coffee, Jr., Class Action Accountability: Reconciling Exit, Voice, and Loyalty in Representative Litigation, 100 COLUM. L. REV. 370, 406-09 (2000) (describing the Lazy Oil decision and other decisions approving settlements over the objection of class representatives).

22. See, e.g., Fisch, supra note 10, at 174 n.43 (citing study describing lack of class representative attendance at settlement conferences).

23. See, e.g., Maywalt v. Parker \& Parsley Petroleum Co., 67 F.3d 1072, 1078 (2d Cir. 1995).

24. Class members in securities fraud litigation may, of course, continue to hold stock in the defendant corporation. In such cases, class members may prefer governance-type reforms that have the effect of deterring future misconduct to money damages. Moreover, to the extent that class members are risk-neutral diversified investors, their overall interest in litigation that produces money damages is limited to the extent that such damages simply result in transfer payments from one class of stockholders to another. See Janet Cooper Alexander, Rethinking Damages in Securities Class Actions, 48 STAN. L. REV. 1487, 1504-05 (1996). 
hood that further pursuit of the litigation might substantially increase the total class recovery. ${ }^{25}$

Counsel also may be more risk averse than the members of the plaintiff class. Because plaintiffs' lawyers make an investment in the case, they may favor the certainty associated with an early settlement over the prospect of a larger but riskier recovery after extended litigation. ${ }^{26}$

Although statutes require judicial review of settlement decisions, as Jonathan Macey and Geoffrey Miller explain, courts are in a poor position to review settlement proposals effectively. ${ }^{27}$ Judges are structurally biased in favor of settlement, both as a personal matter-it clears their overcrowded calendars - and because of an institutional ethos that courts should encourage resolution of litigation by settlement. ${ }^{28}$ Moreover, because a deferential standard of review is applied to judicial approval of settlements, these biases are unlikely to be corrected on appellate review. ${ }^{29}$ Even well-motivated judges are poorly served by the settlement evaluation process. Because the record before the court is both incomplete and under the control of the litigants, judges lack sufficient information to evaluate the fairness of a proposed settlement. ${ }^{30}$ The task is further complicated by the fact that settlement hearings are typically nonadversarial processes in which the presentation of information is jointly orchestrated by plaintiffs and defendants. ${ }^{31}$

The process for determining the appropriate compensation for class counsel is also problematic. Securities fraud class actions are common fund cases, in which the court determines the appropriate fee for plaintiffs' counsel at the conclusion of the case and orders the fee to be paid from the damages recovered for the plaintiff class. ${ }^{32}$ Courts have developed different methods of computing an appropriate fee. The major divide is between those who advocate using the lodestar basis, which compensates lawyers for the time they devote to the case, and those who favor paying lawyers a percentage of the recovery obtained. ${ }^{33}$ As numerous commentators have observed, however, both the lode-

25. In re Oracle Sec. Litig., 829 F. Supp. 1176, 1179 (N.D. Cal. 1993).

26. See, e.g., John C. Coffee, Jr., Rescuing the Private Attorney General: Why the Model of the Lawyer as Bounty Hunter is Not Working, 42 MD. L. REV. 215, 230 (1983) (explaining this possibility).

27. See Macey \& Miller, supra note 9, at 44-48.

28. See id. at 45-46.

29. See, e.g., Kahn v. Sullivan, 594 A.2d 48, 63 (Del. 1991) (refusing to "second-guess" the discretion of the Court of Chancery in approving the "meager" settlement of lawsuit challenging corporate philanthropic expenditure despite objections by various shareholders, including the California Public Employees Retirement System ("CalPERS")).

30. See Macey \& Miller, supra note 9 , at 46.

31. See id. at $46-47$.

32. See, e.g., Monique Lapointe, Note, Attorney's Fees in Common Fund Actions, 59 FordHam L. REV. 843, 844-45 (1991) (describing procedure for determining fee awards in common fund cases).

33. Although the lodestar method enjoyed a period of widespread popularity, seemingly because courts were comfortable with the concept of calculating fees on an hourly basis, the more recent trend in common fund cases has been toward a return to the percentage-of-recovery method. See Janet Cooper Alexander, Contingent Fees and Class Actions, 47 DEPAUl L. REV. 347, 349 (1998). 
star and the percentage-of-recovery methods produce incentive problems. ${ }^{34}$ These problems are heightened when a case is settled. ${ }^{35}$

Moreover, the ex post judicial determination of attorneys' fees in a class action differs markedly from the pricing process in a competitive market. ${ }^{36}$ First, the decision about how much to pay is divorced from the selection decision. The court generally does not consider a firm's standard billing rate or contingency fee when it makes the decision to appoint the firm as lead counsel at the beginning of the case, nor does the court weigh the firm's typical fees against those of its competitors. Instead, the court selects the firm based on other factors and reserves control over the fee award. Second, the fee award generally reflects an assessment of factors unique to the case at bar, such as the performance of the attorneys and the degree of risk associated with the case. ${ }^{37}$ A firm does not typically seek to justify a fee request by pointing to the amount of compensation it received in prior cases. ${ }^{38}$ Finally, the court's award is made with knowledge of the outcome of the litigation. Unlike traditional retention agreements, which are made before the parties know the timing and amount of the recovery, the court's fee determination can reflect the court's evaluation of the quality of the services that the firm actually has provided.

Although courts could consequently take advantage of hindsight to base fee awards on counsel's performance, they have shown little willingness to do so. Instead, courts have found it difficult to resist institutional pressure to award "benchmark" levels of compensation. ${ }^{39}$ Departures from a specified percentage

34. For detailed explanations of the lodestar and percentage of recovery methods and the incentive and administrative problems associated with each, see Coffee, supra note 13, at 887-89; Macey \& Miller, supra note 9, at 50-61; Andrew K. Niebler, In Search of Bargained-For Fees for Class Action Plaintiffs' Lawyers: The Promise and Pitfalls of Auctioning the Position of Lead Counsel, 54 BUS. LAW. 763, 770-74 (1999).

35. See Macey \& Miller, supra note 9, at 48-49 (explaining that judges are reluctant to reject fee agreements in settlement packages for fear of upsetting the settlement).

36. See In re Oracle Sec. Litig., 131 F.R.D. 688 (N.D. Cal. 1990) (concluding that neither the lodestar method nor a benchmark percentage-of-recovery are effective substitutes for determining the fair market value of counsel's services at the outset of common fund litigation).

37. In a common fund case, these factors are generally reflected in the court's selection of a multiplier. See, e.g., Savoie v. Merchants Bank, 166 F.3d 456, 460 (2d Cir. 1999). In a percentage-of-recovery case, the court looks to these factors in setting the percentage. See, e.g., Brown v. Phillips Petroleum Co., 838 F.2d 451, 454-55 (10th Cir. 1988).

38. Under the lodestar method, however, the court must determine a reasonable hourly rate, which is based on the rates charged by lawyers of similar skill and experience in the community.

39. See Goldberger v. Integrated Resources, Inc., 209 F.3d 43, 51 (2d Cir. 2000) ("[W]e concede that district courts across the nation have apparently eased into a practice of 'systematically' awarding fees in the $25 \%$ range, 'regardless of type of case, benefits to the class, numbers of hours billed, size of fund, size of plaintiff class, or any other relevant factor." (quoting Third Circuit Task Force, Court Awarded Attorney Fees, 108 F.R.D. 237, 247 n.32 (1986) (collecting cases)); see also Stuart J. Logan \& Beverly C. Moore, Jr., Attorney Fee Awards In Common Fund Securities \& Antitrust Class Actions, 13 ClASS ACTION REP. 249, 546 (1990) (analyzing 334 common fund securities cases and finding that in the 48 cases that generated a common fund between $\$ 1$ million and $\$ 2$ million, the attorneys received $28.3 \%$ of the fund as an average fee and expense award); Declaration of John C. Coffee, Jr., Aug. 17, 1998, at 7 n.4, In re Cendant Litig., 182 F.R.D. 144 (D.N.J. 1998) (No. 98-CV-1664 (WHW) [hereinafter Coffee Declaration] (describing the "fullest recent study" as showing that $32 \%$ is the prevailing benchmark). 
of the recovery are rare, regardless of the fact that cases vary tremendously with respect to factors such as the difficulty of the case, the hours invested by counsel, and the degree of risk associated with the recovery. ${ }^{40}$ Of particular concern is the repeated award of substantial attorneys' fees in cases in which the court acknowledges that counsel's efforts have produced minimal benefit to the plaintiff class. ${ }^{41}$ This problem is aggravated by the fact that, in most cases, the litigation outcome involves a negotiated settlement. If, as indicated above, a court cannot effectively review the quality of a settlement, it is further handicapped in evaluating the legal services that produced that settlement. ${ }^{42}$

As a result, attorneys' fee awards in class actions are poorly correlated with the performance of class counsel. Despite the value of performance-based compensation, ${ }^{43}$ it has effectively been abandoned as a monitoring tool in class actions. These developments are coupled with a process in which counsel selects the client rather than the client selecting a lawyer, and in which class members exercise little or no authority over counsel's litigation decisions. Therefore, the class action structure may, on occasion, result in inappropriate litigation decisions, and judicial fee awards may over- or under-compensate plaintiffs' counsel.

\section{B. The Response of the PSLRA}

Although the public relations spin associated with the PSLRA focused on the evils of strike suits and lawyer-driven litigation, ${ }^{44}$ the statute may fairly be read as an effort to reform class action procedures to secure more effective client control. ${ }^{45}$ Congress viewed greater client control as a means to address the

40. Judge Kram's recent fee decision in the Drexel Burnham class action is a notable counterexample. See Goldberger, 209 F.3d at 46-47 (describing fee applications and Judge Kram's fee award). Using the lodestar method, Judge Kram awarded plaintiff's counsel a fee of approximately four percent of the $\$ 54$ million recovery provided to the class by virtue of a settlement. Despite counsel's objections to the fee as a substantial departure from the $25 \%$ "benchmark" in the profession, Judge Kram concluded that a multiplier was unwarranted. Judge Kram's decision was upheld on appeal by the Second Circuit. See id. at 57. In particular, the Second Circuit observed that the $25 \%$ benchmark reflected a contingency risk that was unlikely to be present in every securities fraud class action, and noted that, in the absence of a substantial contingency risk, a $25 \%$ contingency fee was unreasonable. See id. at 51-54.

41. See, e.g., In re QVC, Inc. Shareholders Litig., No. 13950-NC, 1997 Del. Ch. LEXIS 14, at*6-7, 13 (Del. Ch. Feb. 5, 1997) (awarding \$1 million in legal fees to counsel despite judicial findings suggesting that counsel's efforts were of little value to plaintiff class); Weiss \& Beckerman, supra note 16, at 2072-74 (criticizing award of counsel fees in "piggyback" derivative suit in Oracle). But see Kaplan v. Rand, 192 F.3d 60, 72 (2d Cir. 1999) (overturning district court \$1 million fee award and finding no fees justified because settlement "provided no substantial benefit to the corporation or its shareholders").

42. Additionally, fee awards are subject to a particularly deferential standard of appellate review. See Goldberger, 209 F.3d at 47-48 ("“[A]buse of discretion'-already one of the most deferential standards of review-takes on special significance when reviewing fee decisions.").

43. See, e.g., Randall S. Thomas \& Kenneth J. Martin, The Effect of Shareholder Proposals on Executive Compensation, 67 U. CIN. L. REV. 1021, 1025 (1999) (describing a trend toward and rationale for performance-based executive compensation).

44. See, e.g., Jill E. Fisch, Class Action Reform: Lessons from Securities Litigation, 39 ARIZ. L. REV. 533, 535 (1997) (recounting descriptions of abusive litigation provided to Congress during legislative hearings).

45. See, e.g., CONF. REP., supra note 19, at 32 (statute would protect investors "against lawyerdriven lawsuits by giving control of the litigation to lead plaintiffs."); COMMITTEE ON BANKING, 
potential for abuse of the litigation process. ${ }^{46}$ The PSLRA created a formal mechanism for the appointment of a lead plaintiff. ${ }^{47}$ The lead plaintiff provision was intended to reduce agency costs by encouraging investors with substantial stakes, particularly institutional investors, to participate more actively in litigation decisionmaking. ${ }^{48}$

The PSLRA contains detailed guidelines for the selection of the lead plaintiff. Following the initial filing of a securities fraud class action, the filing plaintiff must publish notice of the suit and advise class members of the opportunity to seek appointment as lead plaintiff. ${ }^{49}$ Any member of the plaintiff class can subsequently file a motion to be appointed lead plaintiff. Within ninety days after publication of the notice, the court is required to appoint as lead plaintiff the "member or members of the purported plaintiff class that the court determines to be most capable of adequately representing the interests of class members." The statute provides a rebuttable presumption that the most adequate plaintiff is the person or group with the largest financial interest in the claim. ${ }^{51}$ The legislative history of the PSLRA suggests that Congress particularly intended to encourage institutional investors to seek appointment as lead plaintiff. ${ }^{52}$ Following appointment, the lead plaintiff is responsible for choosing class counsel. The statute provides that " $[\mathrm{t}]$ he most adequate plaintiff shall, subject to the approval of the court, select and retain counsel to represent the class." ${ }^{53}$ Thus, Congress sought to reverse the then-prevalent practice of counsel choosing the plaintiff rather than the plaintiff choosing counsel..$^{54}$

The adoption of the lead plaintiff provision already has changed the conduct of securities fraud litigation. First, the statute appears to be encouraging institutional investor participation in litigation, the effect contemplated by Congress. An increasing number of institutional investors are seeking appointments

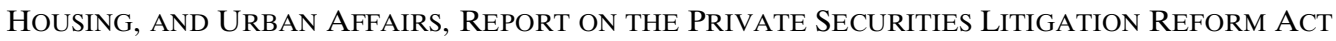
OF 1995, S. REP. NO. 104-98, at 6 (1995), reprinted in 1995 U.S.C.C.A.N. 679, 685 [hereinafter S. REP.] (Congress intends "to transfer primary control of private securities litigation from lawyers to investors."); id. at 10 ("[T] he lead plaintiff-not lawyers-should drive the litigation.").

46. See, e.g., CONF. REP., supra note 19, at 31 (describing evidence of abusive practices including the filing of meritless litigation, the targeting of deep pocket defendants without regard to their actual culpability, discovery abuses, and manipulation by lawyers of their clients); S. REP., supra note 45, at 612 (describing findings of abusive practices).

47. The provision was modeled on a proposal in a Yale Law Journal article by Professors Elliott Weiss and John Beckerman. See Weiss \& Beckerman, supra note 16, at 2105-08.

48. See CONF. REP., supra note 19, at 32 (lead plaintiff provisions are "intended to encourage the most capable representatives of the plaintiff class to participate in class action litigation and to exercise supervision and control of the lawyers for the class."); id. at 34 ("[I]ncreasing the role of institutional investors ... will ultimately benefit shareholders and assist courts by improving the quality of representation....").

49. See 15 U.S.C. $\$ 78 u-4(a)(3)(A)(i)$ (Supp IV. 1998).

50. $I d . \S 78 \mathrm{u}-4(\mathrm{a})(3)(\mathrm{B})(\mathrm{i})$.

51. See id. § 78u-4(a)(3)(B)(iii).

52. See CONF. REP., supra note 19 , at 34 .

53. 15 U.S.C. $\$ 78 u-4(a)(3)(B)(v)$.

54. See CONF. REP., supra note 19 , at 35 . 
as lead plaintiff..$^{55}$ Consistent with this participation, institutional investors are rationalizing shareholder litigation within their approach to corporate governance. Institutions are developing guidelines to determine when their participation in shareholder litigation is desirable. ${ }^{56}$ Institutions are developing ongoing relationships with plaintiffs' firms and increasing sophistication in evaluating and negotiating fee arrangements. ${ }^{57}$ Although it is too early to tell, institutional participation may also be affecting litigation outcomes. ${ }^{58}$

Though a less beneficial consequence, the lead plaintiff provision also slows down the litigation process. Because the filing plaintiff must notify other class members, and because potential lead plaintiffs must be given time to seek appointment, there is a waiting period after the initial filing during which the case is essentially on hold. ${ }^{59}$ In particular, no firm can know whether it will be appointed lead counsel; therefore, no lawyer is in a position to begin discovery or initiate settlement negotiations. The delay associated with the lead plaintiff

55. Initially, institutional involvement was limited. See SEC OFFICE OF THE GENERAL COUNSEL, REPORT TO THE PRESIDENT AND THE CONGRESS ON THE FIRST YeAR OF PRACTICE UNDER THE Private SECURITIES LitigAtion REFORM ACT OF 1995 (Apr. 1997) (visited Feb. 16, 2001) $<$ http://www.sec.gov/news/studies/lreform.txt> (reporting that "institutional investors have not become active in many cases"). More recently, large institutional investors have sought to participate in a number of cases. See, e.g., In re Network Assocs. Inc. Sec. Litig., 76 F. Supp. 2d 1017, 1030-31 (N.D. Cal. 1999) (appointing the Board of Pensions and Retirement of the City of Philadelphia as presumptive lead plaintiff); In re Telxon Corp. Sec. Litig., 67 F. Supp. 2d 803, 819-20 (N.D. Ohio 1999) (rejecting Florida State Board of Administration's application to be appointed lead plaintiff); In re Cendant Corp. Litig., 182 F.R.D. 144, 147, 151 (D.N.J. 1998) (appointing lead plaintiff group consisting of California Public Employees' Retirement System, the New York State Common Retirement Fund, and the New York City Pension Funds).

56. See, e.g., Teachers' Retirement Board draft policy for CalSTERS' involvement in securities litigation matters (visited Jan. 5, 2000) <http://www.calstrs.cagov/feedback/contact.html> (developing policy guidelines for CalSTRS' involvement in securities litigation).

57. A number of institutions have conducted active searches, selected litigation counsel in their capacity as lead plaintiff, and negotiated fee agreements designed to reduce litigation costs and minimize agency costs. See, e.g., In re Waste Management, Inc. Sec. Litig., No. H99-2183 (S.D. Tex. May 8, 2000), at 44 (citing affidavit submitted by Connecticut describing its negotiation of a fee schedule with proposed lead counsel providing for lower fees than those typically awarded in securities fraud class actions); Daniel Wise, Big Apple, Empire State vie to Control Stock Suit, NAT'L L.J., July 19, 1999, at A5 [hereinafter Wise, Big Apple] (quoting assistant corporation counsel Hilary Klein as stating that the city's fee agreement with its counsel in McKesson case provides for fees of less than $10 \%$ of the recovery); Daniel Wise, NYC Moves to Slash Cendant Fees, 222 Legal InTELlig. 4, 4 (2000) [hereinafter Wise, NYC Moves to Slash Cendant Fees] (describing retainer agreement between the three lead plaintiff pension funds and their counsel in the Cendant case); Keith L. Johnson \& Richard H. Koppes, Cellstar and Cal Micro Cases Provide New Model for Securities Fraud Litigation, 1999 A.L.I.-A.B.A. CORPORATE GOVERNANCE INST., Oct. 7, 1999, at 537, 542 (describing success of State of Wisconsin Investment Board in negotiating a competitive fee agreement in Gluck v. Cellstar Corp., 976 F. Supp. 542 (N.D. Tex. 1997)); Kansas Public Employees Retirement System Search for Outside Securities Litigation Counsel/Request for Proposals (June 1999) (on file with author).

58. In Cendant, for example, in which three public pension funds served as lead plaintiff, the case was resolved by a $\$ 3.1$ billion settlement. See Wise, NYC Moves to Slash Cendant Fees, supra note 57, at 4 .

59. If questions about the form and type of notice result in collateral litigation, they can further extend this waiting period. For example, the court in Lucent, after rejecting what was essentially the standard form and medium for notice, ordered publication of a revised notice. See In re Lucent Technologies, Inc., Sec. Litig., 194 F.R.D. 137, 148 (D.N.J. 2000). The court then appointed a provisional lead plaintiff, pending receipt of motions from other interested class members. See id. at 154-55. 
provision is exacerbated if the court uses an auction process to select lead counsel, as described below. ${ }^{60}$ Moreover, the subsequent step in litigation under the PSLRA is virtually always a motion to dismiss by the defendant, ${ }^{61}$ and, under the statute, the defendant is entitled to a stay of discovery pending resolution of the motion. ${ }^{6}$

These factors, in combination, can result in substantial delay. The record in Network Associates illustrates the extent to which litigation over the lead plaintiff provision can delay a case. The first complaint in the case was filed on April 7, 1999. ${ }^{63}$ The court was not successful in appointing a lead plaintiff until December 15,$1999 ;{ }^{64}$ lead counsel was not appointed until January $24,2000,{ }^{65}$ and the case was subsequently stayed by the Ninth Circuit while it reviewed writ requests challenging those decisions until March 27, 2000. ${ }^{66}$ Thus, after almost an entire year of litigation, the defendants had not even responded to the complaint. ${ }^{6}$

The statute grants the lead plaintiff authority to select class counsel; accordingly, the selection of lead plaintiff is generally linked to the appointment of lead counsel. ${ }^{68}$ Plaintiffs' firms appreciate this linkage and recognize that representation of the lead plaintiff is the new ticket to the courthouse. Consequently, firms are developing a variety of methods for identifying and recruiting clients to serve as lead plaintiffs, with the expectation that if the firm's client is appointed lead plaintiff, the firm's appointment as lead counsel will follow. ${ }^{69}$

Firms have approached the challenge of securing lead counsel appointments in a variety of ways. One approach is to assemble a large group of investors,

60. See infra Part IV.

61. See, e.g., Richard H. Walker et al., The New Securities Class Action: Federal Obstacles, State Detours, 39 ARIZ. L. REV. 641, 665 (1997) (explaining that plaintiffs' attorneys can expect at least one and possibly several motions to dismiss); see also Hillary A. Sale, Heightened Pleading and Discovery Stays: An Analysis of the Effect of the PSLRA's Internal-Information Standard on '33 and '34 Act Claims, 76 WASH. U. L.Q. 537 (1998) (describing motions to dismiss under the PSLRA); Elliott J. Weiss, The New Securities Fraud Pleading Requirement: Speed Bump or Road Block?, 38 ARIZ. L. REV. 675 (1996) (same).

62. See, e.g., Walker et al., supra note 61, at 665 (describing the new discovery stay as "an added incentive for a motion to dismiss").

63. See In re Network Assocs., Inc., Sec. Litig., 76 F. Supp. 2d 1017, 1019 (N.D. Cal. 1999).

64. See Order Supporting Robert A. Vatuone as Lead Plaintiff, Dec. 15, 1999, In re Network Assocs., Inc., Sec. Litig. 76 F. Supp. 2d 1017 (N.D. Cal. 1999) (No. C99-01729), available at (visited Mar. 24, 2001) <http:// securities.stanford.edu/decisions/neta/ 99cv01729/189.html>.

65. See Order Appointing Class Counsel, Jan. 24, 2000, Network Assocs, (No. C99-01729), available at (visited Mar. 24, 2002) <http://securities.stanford.edu/decisions/neta/99cv01729/ 000124or.html>.

66. See 9th Cir. Lifts Stay in Network Associates Lead Plaintiff Decision, supra note 7, at 11 (describing decision by Ninth Circuit refusing to review the decision and lifting the previously ordered stay).

67. See Order Appointing Class Counsel, supra note 65 (ordering lead plaintiff to file a first amended complaint and ordering defendants to respond). This order was stayed pending resolution of the writ requests. See 9th Cir. First to Address Class Representative, Counsel Selection Under PSLRA, PENSION FUND. LiTIG. REP., Apr. 24, 2000, at 4 (explaining procedural history of case).

68. But see infra note 269 and accompanying text.

69. See Walker et al., supra note 61, at 657 (describing how plaintiffs' firms are using the statutorily required notice to recruit investors as additional members of a would-be lead plaintiff group). 
which the firm proposes in the aggregate as a candidate for lead plaintiff. ${ }^{70}$ If the court accepts the premise that a group of unrelated investors can serve as lead plaintiff and that the holdings of individual group members should be aggregated for the purpose of calculating the group's financial interest, then a firm can secure appointment as lead counsel by virtue of creating the largest lead plaintiff group. Part III below considers judicial responses to such aggregation strategies and the consistency of this approach with the PSLRA.

Competition for lead counsel appointments has led to contentiousness. Firms have debated the propriety of aggregation ${ }^{71}$ and have challenged the qualifications of competing lead plaintiff applicants. ${ }^{72}$ In some cases, the competition has deteriorated into mudslinging and attacks on the character of competing lead plaintiff applicants ${ }^{73}$ and their counsel. ${ }^{74}$ As a result, some courts have been reluctant to defer to the lead plaintiff's choice of counsel. Moreover, the PSLRA provides relatively little guidance on these issues. The statute neither supplies the court with criteria for reviewing the lead plaintiff's choice of counsel nor explains the consequences if the court, pursuant to its statutory authority, rejects the plaintiff's selection. In addition, the statute does not explicitly disturb the court's traditional authority over the award of attorneys' fees.

70. An alternative approach is to develop ongoing relationships with institutional investors. It is relatively easy to identify institutions that have sufficient investment holdings to qualify as lead plaintiffs and that might be willing to serve. A law firm that cultivates such an institution as a client faces a substantial likelihood of being appointed lead counsel on a regular basis. Although institutions may differ from the potential plaintiff lists maintained by plaintiff firms prior to the PSLRA, see Weiss \& Beckerman, supra note 16, at $2061 \mathrm{n} .35$, they serve a similar function in providing the attorney with access to the lead counsel position. As I observed in an earlier article, the PSLRA creates a potentially lucrative role as institutional counsel of choice, but it raises new issues about the manner in which institutions exercise that choice. See Fisch, supra note 44, at 548-50.

71. See, e.g., In re Telxon Corp. Sec. Litig., 67 F. Supp. 2d 803, 809-11 (N.D. Ohio 1999) (describing debate among competing lead plaintiff applicants as to the propriety of appointing a group of unrelated investors and aggregating their holdings).

72. See, e.g., In re McKesson HBOC, Inc., Sec. Litig., 97 F. Supp. 2d 993, 995 (N.D. Cal. 1999) (describing competing claims by New York City and New York State of the largest financial interest in the litigation); Telxon, 67 F. Supp. 2d at 817 (explaining objections by competing group to the appointment of Florida State Board of Administration because the FSBA had already served as lead plaintiff in five cases within the past three years and because it was subject to unique defenses); In re Advanced Tissue Sciences Sec. Litig., 184 F.R.D. 346, 350 (S.D. Cal. 1998) (recounting dispute by competing groups over the amount of their respective losses and over the weight that should be given to this factor).

73. See, e.g., In re Waste Management, Inc. Sec. Litig., No. H99-2183 (S.D. Tex. May 8, 2000), at 41 (describing allegation by WMPG Group that the Treasurer of the State of Connecticut is too busy to monitor the litigation because she is occupied with the investigation of her predecessor who pled guilty to federal racketeering charges).

74. See, e.g., NALPG's Opposition to Weiss \& Yourman Motion and Vatuone Motion for Appointment of Lead Plaintiff and Lead Counsel Pursuant to Section 21D(A)(3)(B) of the Securities Exchange Act of 1934, Oct. 14, 1999, In re Network Assocs., Inc., Sec. Litig., 76 F. Supp. 2d 1017 (N.D. Cal. 1999) (No. 99-1729) [hereinafter NAPLG Opposition in Network Assocs.) (describing Weiss \& Yourman's behavior in recruiting investors as felonious, duplicitous, and unethical); In re Cendant Corp. Litig., 182 F.R.D. 144, 148-49 (D.N.J. 1998) (recounting "pay-to-play" allegations charging counsel to CalPERS with making substantial contributions to the campaign of the New York State Comptroller); Paul Elias, Lead Counsel Battle Doesn't Impress Ware, RECORDER, Sept. 7, 1999, at 4 (describing unsuccessful motion to disqualify Milberg Weiss from serving as co-lead counsel in In re 3Com Sec. Litig. based on allegations of a conflict of interest). 
Consequently, several judges have severed the link between the appointments of lead plaintiff and lead counsel by taking over the selection of lead counsel. ${ }^{75}$ Using variations on a process first employed by Judge Vaughn Walker in the Oracle case ${ }^{76}$ these judges have conducted sealed bid auctions for the purpose of determining lead counsel. Part IV below considers the implications of this procedure.

III

\section{LEAD Plaintiff GROUPS AND AgGRegation}

\section{A. The Appointment of Multiple Investors}

The statutory basis for the appointment of a lead plaintiff group is section 21D(3)(B)(iii) of the PSLRA, which contains the only use of the term "group." In the section dealing with the appointment of the "most adequate plaintiff," the statute instructs the court to "adopt a presumption that the most adequate plaintiff ... is the person or group of persons ... that has the largest financial interest in the relief sought by the class...." The propriety of aggregation thus depends on the interpretation of the term "group."

Courts have taken three approaches. Some courts have interpreted the term "group" broadly to permit the appointment of large groups of unrelated investors as lead plaintiff. ${ }^{79}$ Several courts have adopted a narrow view in which a lead plaintiff must either be a single investor or a closely-knit group. ${ }^{80}$ Most courts have opted for the middle ground. Following the SEC's rule of reason, these courts have accepted aggregation, but appointed groups that are limited

75. See, e.g., In re Lucent Techs., Inc., Sec. Litig., 194 F.R.D. 137 (D.N.J. 2000) (ordering lead counsel auction); Sherleigh Assocs. LLC v. Windmere-Durable Holdings, Inc., 184 F.R.D. 688 (S.D. Fla. 1999) (ordering selection of counsel through sealed bid auction procedure); Wenderhold v. Cylink Corp., 188 F.R.D. 577 (N.D. Cal. 1999) (selecting counsel on the basis of submitted bids).

76. See In re Oracle Sec. Litig., 136 F.R.D. 639 (N.D. Cal. 1991), 132 F.R.D. 538 (N.D. Cal. 1990), 131 F.R.D. 688 (N.D. Cal. 1990).

77. 15 U.S.C. $\$ 78 u-4(a)(3)(B)(i i i)(I)$ (Supp. IV 1998) provides that the court

shall adopt a presumption that the most adequate plaintiff in any private action arising under this chapter is the person or group of persons that-

(aa) has either filed the complaint or made a motion in response to a notice under subparagraph (A)(i);

(bb) in the determination of the court, has the largest financial interest in the relief sought by the class; and

(cc) otherwise satisfies the requirements of Rule 23 of the Federal Rules of Civil Procedure.

Id. (emphasis added).

78. Id.

79. See, e.g., Aronson v. McKesson HBOC, Inc., 79 F. Supp. 2d 1146, 1153 (N.D. Cal. 1999) (explaining that many courts have adopted this broad approach under which "any conglomeration [of investors] will do").

80. See id. at 1153-54 (adopting narrow view of group); Sakhrani v. Brightpoint, Inc., 78 F. Supp. 2d 845,854 (S.D. Ind. 1999) (rejecting aggregation in favor of appointing a single investor as lead plaintiff). 
in size..$^{81}$ Notably, in addition to their disagreement over the propriety of aggregation, courts also disagree on the current state of the law. For example, the court in Network Associates stated in November 1999 that no court has designated a large aggregation of unrelated investors as lead plaintiff. ${ }^{82}$ In January 2000, the First Union court reached the opposite conclusion, stating that the "overwhelming weight of authority" allowed the appointment of a large, unrelated group..$^{83}$

Courts employing the broad approach have relied on the statutory language that, in addition to authorizing the appointment of a lead plaintiff group, contains no qualifying language or limitations on group size. ${ }^{84}$ Many early cases involved a single unchallenged application for the appointment of a lead plaintiff group. $^{85}$ In addition, the appointment of a group frequently eliminated competition for the lead plaintiff appointment. ${ }^{86}$ In Vesta, ${ }^{87}$ for example, the court claimed that it was unable to resolve the competing motions on the merits and would select the lead plaintiff by tossing a coin. ${ }^{88}$ Motivated by this threat, the competing groups resolved the matter through a stipulation seeking a joint appointment. $^{89}$

81. See, e.g., In re Ribozyme Pharmaceuticals, Inc., Sec. Litig., 192 F.R.D. 656, 662 (D. Colo. 2000) (appointing lead plaintiff group of four investors); In re Nice Sys. Sec. Litig., 188 F.R.D. 206 (D.N.J. 1999) (appointing group of five investors); In re Baan Co. Sec. Litig., 186 F.R.D. 214, 217 (D.D.C. 1999) (appointing triumvirate of investors); City Nominees v. Macromedia, No. C97-3521-SC, slip op. at 2, 6-7 (N.D. Cal. Jan. 23, 1998) (refusing to appoint group of 36 investors but accepting alternative proposal of six persons as a "permissible, but suboptimal, result").

82. See In re Network Assocs., Inc., Sec. Litig., 76 F. Supp. 2d 1017, 1022 (N.D. Cal. 1999) ("The decisions have flat-out refused to appoint 'large amalgamations of unrelated persons as lead plaintiff.'") (quoting In re Advanced Tissue Sciences Sec. Litig., 184 F.R.D. 346, 352 (S.D. Cal. 1998)).

83. In re First Union Corp. Sec. Litig., No. 3:99CV237-MCK, 2000 U.S. Dist. LEXIS 2267 , at *12 (W.D.N.C. Jan. 28, 2000).

84. See, e.g., D'Hondt v. Digi Int'l, Inc., No. 97-5 (JRT/RLE), 1997 U.S. Dist. LEXIS 17700, at *13 (D. Minn. Apr. 3, 1997) ("[A]n arbitrary limit on the number of proposed Lead Plaintiffs would be unrealistic if not wholly counterproductive."); In re Cephalon Sec. Litig., No. 96-CV-0633, 1996 U.S. Dist. LEXIS 13492, at *2 (E.D. Pa. Aug. 27, 1996) ("[T] he Act does not preclude appointing more than one lead plaintiff," and, as a result, "plaintiffs' motion requesting the appointment of several lead plaintiffs does not violate the Act").

85. See First Union, 2000 U.S. Dist. LEXIS 2267, at *9-10 (citing long list of cases in which court appointed lead plaintiff groups ranging in size from 10 to 30 investors).

86. See, e.g., Stipulated Order Appointing Lead Plaintiff and Approving Co-Lead Counsel, Nov. 10, 1998, LaPerriere v. Vesta Ins. Group, Inc., No. CV-98-AR-1407-S (N.D. Ala. Oct. 19, 1998) (accepting stipulation seeking co-lead plaintiff appointment by preciously competing movants); Nager v. Websecure, Inc., No. 97-10662-GAO, 1997 U.S. Dist. LEXIS 19601, at *3, (D. Mass. Nov. 26, 1997) (appointing group of 10 lead plaintiffs and three lead counsel from five previously filed complaints); Zuckerman v. Foxmeyer Health Corp., No. 3:96-CV-2258-T, 1997 U.S. Dist. LEXIS 23549, at *4 (N.D. Tex. Mar. 28, 1997) (granting joint motion by group comprised of formerly competing movants over the objection of the defendant); see First Union, 2000 U.S. Dist. LEXIS 2267 (accepting stipulation resolving competing motions for lead plaintiff by proposing appointment of both groups as co-lead plaintiffs).

87. LaPerriere v. Vesta Ins. Group, No. CV-98-AR-1407-S (N.D. Ala. 1998).

88. Order, Oct. 19, 1998, LaPerriere v. Vesta Ins. Group, No. CV-98-AR-1407-S (N.D. Ala. 1998).

89. See Peter M. Saparoff \& Adam L. Sisitsky, The Role of Institutional Investors in Class Actions Under the PSLRA-Are They Walking on a Slippery Slope? Two Years Later, A.L.I.-A.B.A. SEC. Litig.: PlanNing \& STRATEgIES, Apr. 30, 1999, at 919, 924-25 (describing Vesta litigation); see also Memorandum of the SEC, Amicus Curiae, LaPerriere v. Vesta Ins. Group, Inc., No. CV-98-AR-1407-S 
A few courts have also based their acceptance of aggregation on the benefits of a lead plaintiff group relative to the appointment of a single investor. ${ }^{90}$ The Oxford court's decision contains the most extensive discussion on this point. ${ }^{91}$ The court reasoned that a lead plaintiff group would provide a number of benefits, including pooled knowledge and resources, joint decisionmaking, and joint funding. Similarly, a group combining individual and institutional investors can address concerns about the representativeness of the lead plaintiff. ${ }^{92}$

The possibility that a court will allow aggregation without limit or, in the alternative, appoint a subgroup from the largest lead plaintiff group, has led some plaintiffs' firms to attempt to secure the lead counsel appointment by obtaining the largest portfolio of plaintiffs. Firms have assembled hundreds or even thousands of investors into lead plaintiff groups. The court in Network Associates faced two competing groups, one consisting of more than 1725 investors and the other consisting of "over 100 institutions and thousands of individuals." submitted by investors indicating their willingness to serve as lead plaintiffs were collected by counsel, bundled into "numerous thick booklets," and submitted to the court in "heavy boxes." Similarly, the court in McKesson faced motions from groups that included as many as 4000 investors. ${ }^{95}$

In more recent decisions, courts have been reluctant to accept the appointment of a large lead plaintiff group, reasoning that a large group cannot function effectively. ${ }^{96}$ In many cases, however, the court chooses the lead plaintiff and its counsel on the basis of the larger group's holdings and then limits its appointment to a smaller group or subgroup. ${ }^{97}$ If the court bases its selection on overall aggregate holdings, it creates an incentive for counsel to assemble large portfolios of unrelated investors. ${ }^{98}$

A combination of distaste for the competition to create and manipulate lead plaintiff groups and skepticism over the ability of such groups to function effectively has led several courts to reject aggregation altogether. Under the narrowest reading of the statute, these courts have reasoned that the use of a group

(N.D. Ala. 1998) [hereinafter Vesta Amicus Brief] (arguing against the appointment of co-lead plaintiffs), available at (visited March 26, 2001) < http://www.sec.gov/news/legal/vestabrf.txt>.

90. See, e.g., D'Hont v. Digi Int'l, Inc., No. 97-5 (JRT/RLE), 1997 U.S. Dist. LEXIS 17700, at*13 (D. Minn. Apr. 3, 1997) ("[W]hen more greatly numbered, the Lead Plaintiffs can more effectively withstand any supposed effort by the class counsel to seize control of the class claims.").

91. See In re Oxford Health Plans, Inc. Sec. Litig, 182 F.R.D. 42 (S.D.N.Y. 1998).

92. See Yousefi v. Lockheed Martin Corp., 70 F. Supp. 2d 1061, 1070-71 (C.D. Cal. 1999) ("[With] the appointment of one lead plaintiff who is an individual private investor and one lead plaintiff that is an institutional investor, the lead plaintiffs will represent a broader range of shareholder interests than if the Court appointed an individual or an institutional investor alone.").

93. In re Network Assocs., Inc., Sec. Litig., 76 F. Supp. 2d 1017, 1019 (N.D. Cal. 1999).

94. Id. at 1022.

95. See Aronson v. McKesson HBOC, Inc., 79 F. Supp. 2d 1146, 1154 (N.D. Cal. 1999).

96. See, e.g., Sakhrani v. Brightpoint, Inc., 78 F. Supp. 2d 845, 853 (S.D. Ind. 1999) (explaining that a large group of unrelated investors could not effectively manage the litigation and oversee class counsel).

97. See id. at 851 (describing and criticizing this process); Network Assocs., 76 F. Supp. 2d at 102324 (same).

98. See Brightpoint, 78 F. Supp. 2d at 851-52. 
is justified only by special circumstances and that ordinarily the appointment of a single investor is preferable. In one of the first decisions to take this approach, Judge Cederbaum observed in Donkenny ${ }^{99}$ that allowing lawyers to designate unrelated plaintiffs as a group would allow and encourage lawyers to direct the litigation. Refusing to accept multiple lead plaintiffs, the judge chose a single institutional investor. ${ }^{100}$ Similarly, the court in Wenderhold v. Cylink Corp. ${ }^{101}$ explained that plaintiff groups are appropriate only in rare circumstances, such as when they are necessary to address multiple class periods or when appointing a group increases client control over the lawyers. ${ }^{102}$ Accordingly, the court appointed a single individual as lead plaintiff. More recently, the court in Network Associates criticized the use of either a large lead plaintiff group or a smaller subgroup and concluded that a single candidate should be chosen over an artificially aggregated group of investors. ${ }^{103}$

The vast majority of decisions have taken a middle position, permitting the appointment of a group of unrelated investors but limiting the group to a "reasonable" size..$^{104}$ This is consistent with the position of the SEC. ${ }^{105}$ Although it has taken the position that large lead plaintiff groups reduce client control and are contrary to the purpose of the statute, the SEC has not argued that either aggregation or the use of lead plaintiff groups is improper. ${ }^{106}$ Instead, the SEC suggests that courts scrutinize the ability of group members to monitor and work together and advocates judicial paring down of groups to the minimum size needed. ${ }^{107}$ According to the SEC, courts should ordinarily limit group size to three to five members. ${ }^{108}$

A few courts have resolved concerns about competition or representativeness through the use of multiple or co-lead plaintiffs. Although the terminology used by courts varies, co-lead plaintiffs are generally unrelated plaintiffs initially in competition for the lead plaintiff position. ${ }^{109}$ A court may appoint more than

99. In re Donkenny, Inc., Sec. Litig., 171 F.R.D. 156 (S.D.N.Y. 1997).

100. See id. at 158.

101. 188 F.R.D. 577 (N.D. Cal. 1999).

102. See id. at 586.

103. In re Network Assocs., Inc., Sec. Litig., 76 F. Supp. 2d 1017, 1027-31 (N.D. Cal. 1999).

104. See supra note 81 (citing cases). Some courts have termed this a "rule of reason." See, e.g., In re Lucent Techs., Inc., Sec. Litig., 194 F.R.D. 137, 154 (D.N.J. 2000); In re Party City Sec. Litig., 189 F.R.D. 91, 112 (D.N.J. 1999); Chill v. Green Tree Fin. Corp., 181 F.R.D. 398, 409 (D. Minn. 1998).

105. See, e.g., Memorandum of the SEC, Amicus Curiae, Switzenbaum v. Orbital Sciences Corp., 187 F.R.D. 246 (E.D. Va. 1999) (No. 99-197-A), available at (visited Mar. 21, 2001) $<$ http://www.sec.gov/ news/legal/orbital.htm> (arguing that court should limit proposed lead plaintiff group to a small number capable of managing the litigation, generally three to five investors); Memorandum of the SEC, Amicus Curiae, In re Baan Co. Sec. Litig., 186 F.R.D. 214, 218 (D.D.C. 1999) (No. A.98-2465 (JHG)) [hereinafter Baan Amicus Brief] (same); see also Memorandum of the SEC, Amicus Curiae, In re Network Assocs. Sec. Litig., 76 F. Supp. 2d 1017, 1035, 1052-53 (N.D. Cal. 1999) (No. 9901729 (WHA)) [hereinafter Network Amicus Brief] (summarizing the SEC's position on aggregation).

106. See Network Amicus Brief, supra note 105.

107. See id.

108. See id.

109. The SEC has taken the position that competing movants should not be appointed as co-lead plaintiffs, arguing that such appointments interfere with the lead plaintiff's ability to negotiate retention 
one competing plaintiff as a compromise or to address concerns about the adequacy or typicality of a prospective lead plaintiff. Thus, for example, the Vesta court appointed two groups as co-lead plaintiffs pursuant to a stipulation. ${ }^{110}$ The court in Oxford appointed three sets of investors, including individuals and institutions, as co-lead plaintiffs. ${ }^{111}$ Each co-lead plaintiff in Oxford was represented by separate counsel, ${ }^{112}$ and each was given one vote on litigation decisions. ${ }^{113}$ Finally, the court in Yousefi appointed the two largest investors, an individual and an institution, as co-lead plaintiffs. ${ }^{114}$ The court noted approvingly that "with the appointment of one lead plaintiff who is an individual private investor and one lead plaintiff that is an institutional investor, the lead plaintiffs will represent a broader range of shareholder interests than if the Court appointed an individual or an institutional investor alone."115

\section{B. Aggregation and the PSLRA}

The widespread acceptance of aggregation is troubling. Contrary to the arguments made in some cases, the text of the statute does not require courts to appoint lead plaintiff groups of unrelated investors. Aggregation is inconsistent with the client empowerment objective of the PSLRA and is unsupported by the legislative history. Aggregation is also unsound from a policy perspective. Judicial endorsement of lead plaintiff groups, even those of "reasonable" size, raises a host of implementation issues that transform the appointment process from a relatively objective inquiry into a discretionary inquiry subject to excessive lawyer control, unwarranted judicial intervention, or both.

To accept aggregation, courts must accept two distinct premises. First, they must conclude that the statute permits the lead plaintiff to consist of a group of unrelated investors. Second, courts must conclude that the financial interests of the individual group members should be aggregated in determining the financial interest of the group.

With respect to the first point, courts have based the conclusion that they are authorized to appoint lead plaintiff groups on a single inclusion of the term "group" in the statute. ${ }^{116}$ It is a mistake, however, to conclude that the appearance of the term mandates, or even permits, the appointment of large groups of unrelated investors. Rather, the PSLRA overwhelmingly refers to the lead

agreements and to monitor the effectiveness of counsel. See Vesta Amicus Brief, supra note 89 (arguing "that the Court should not appoint competing applicants as co-lead plaintiffs").

110. See Stipulated Order Appointing Lead Plaintiff and Approving Co-Lead Counsel, Nov. 10, 1998, LaPerriere v. Vesta Ins. Group, Inc., No. CV-98-AR-1407-S (N.D. Ala. 1998) (accepting stipulation seeking co-lead plaintiff appointment by previously competing movants).

111. See In re Oxford Health Plans, Inc. Sec. Litig., 182 F.R.D. 42, 45 (S.D.N.Y. 1998).

112. See id. at 50.

113. See id. at 45.

114. See Yousefi v. Lockheed Martin Corp., 70 F. Supp. 2d 1061, 1064 (C.D. Cal. 1999).

115. Id. at 1071; see also Laborers Local 1298 Pension Fund v. Campbell Soup Co., [2000 Transfer Binder] Fed. Sec. L. Rep. (CCH) II 90,963, at 94,221 (D.N.J. May 17, 2000) (defending institution and two individuals on the basis that "each may bring a unique perspective to the litigation").

116. See supra note 77 . 
plaintiff in the singular, and the single use of the term "group" is something of an anomaly. ${ }^{117}$ Nor is it clear from the statutory text or structure what the term means. As the Telxon court observed, several dictionary definitions suggest that "group" should be read narrowly to encompass investors who share a meaningful relationship independent of the litigation, such as members of a partnership or mutual funds under common management. ${ }^{118}$

Even assuming that the statutory text permits the appointment of a lead plaintiff group, the statute does not instruct courts as to the appropriate calculation of the group's financial interest. ${ }^{119}$ Although several courts have concluded that it is appropriate to calculate the group's interest by adding together the financial interest of each group member, ${ }^{120}$ this conclusion is generally unsupported by careful analysis. ${ }^{121}$ A number of alternative methodologies are possible, including selecting either the group with the largest individual loss within the group or the group with the largest average loss by its members. Adoption of either of these approaches would substantially reduce the frequency with which a group is appointed lead plaintiff. ${ }^{122}$ Moreover, no general principle of federal law supports the propriety of aggregation. Indeed, there is authority to

117. See, e.g., In re Milestone Scientific Sec. Litig., 183 F.R.D. 404, 417 (D.N.J. 1998) ("Significantly, apart from the sole reference to 'a group of persons,' the PSLRA is worded in the singular, providing a mechanism for the appointment of 'the most adequate plaintiff,' not the most adequate plaintiffs."); accord In re Lucent Techs. Inc., Sec. Litig., 194 F.R.D. 137, 154 (D.N.J. 2000); In re Telxon Corp. Sec. Litig., 67 F. Supp. 2d 803, 812 (N.D. Ohio 1999).

118. See Telxon, 67 F. Supp. $2 \mathrm{~d}$ at 813 (distinguishing such a group from a "melange"); see also Sakhrani v. Brightpoint, Inc., 78 F. Supp. 2d 845, 847 (S.D. Ind. 1999) (describing counsel-created aggregates as "artificial" groups). Elliott Weiss, whose scholarship provided the model for the lead plaintiff provision, has stated publicly that the term "group" was added to the statute to clarify the authority of a court to treat affiliated mutual funds as a single investor for the purpose of the statute. See Elliott Weiss, Remarks at Conference on Complex Litigation, Institute for Law \& Economic Policy (Apr. 14, 2000); see also In re Baan Co. Sec. Litig., 186 F.R.D. 214, 224 n.12 (D.D.C. 1999) (citing Weiss \& Beckerman, supra note 16, as suggesting that Congress used the "group" language to encompass associated institutions such as different funds from the same mutual fund group which were technically separate legal entities).

119. Indeed, the courts have had to develop a general test for calculating the size of an investor's financial interest under the statute. See In re Olsten Corp. Sec. Litig., 3 F. Supp. 2d 286, 295 (E.D.N.Y. 1998) (articulating four factor test including: "(1) the number of shares purchased during the class period; (2) the number of net shares purchased during the class period; (3) the total net funds expended during the class period; and (4) the approximate losses suffered during the class period").

120. See, e.g., In re Informix Corp. Sec. Litig., No. C-97-1289-SBA, 1997 U.S. Dist. LEXIS 23687 (C.D. Cal. Oct. 17, 1997) (reasoning that, under the plain meaning of the statute, the group with the largest aggregate loss had the largest financial interest); Order Appointing Lead Plaintiffs, In re Ride, Inc. Sec. Litig., No. C97-402 WD, 1997 U.S. Dist. LEXIS 23689, at*4 (W.D. Wash. Aug. 5, 1997), (finding that "it is clear that the 'financial interest' of plaintiffs aligned together should be computed by aggregating their claims").

121. See, e.g., Brightpoint, 78 F. Supp. 2 d at 851 (criticizing prior courts' failure to analyze method of aggregating group losses).

122. For example, the court in Ride rejected the appointment of group of two investors, one of whom had purchased 36,024 shares and suffered the largest individual loss of any lead plaintiff applicant, in favor of a group of 17 investors in which the largest individual purchase was 9000 shares. See Ride, 1997 U.S. Dist. LEXIS 23689. Similarly, in In re Diamond Multimedia Systems, Inc., Sec. Litig., No. C97-402WD 1997, U.S. Dist. LEXIS 23691 (N.D. Cal. Jan. 13, 1997), the court, without analysis, appointed a seven-member group rather than one individual who had suffered a greater loss than any single member of the group. 
the contrary; "well-settled" principles of federal law prohibit class members from aggregating their claims for the purpose of meeting the amount-incontroversy requirement of diversity jurisdiction. ${ }^{123}$

To the extent that the statute fails to provide clear guidelines for courts in determining what constitutes a proper lead plaintiff group, it is appropriate to consider the statutory objectives. ${ }^{124}$ The PSLRA was designed to "minimize costs' and to 'give control of the litigation to lead plaintiffs with substantial holdings to the securities of the issuer."' 125 The purpose of the lead plaintiff provision is to reduce the collective action problems and agency costs that frustrate class management. ${ }^{126}$ The statute attempts to achieve these objectives by vesting authority for overseeing the litigation in an investor with a sufficient stake to monitor it effectively. This purpose is apparent from numerous elements of the statutory design. ${ }^{127}$

A collection of unrelated individuals cannot effectively exercise client control. Group decisionmaking is, by its very nature, less efficient than individual decisionmaking. ${ }^{128}$ Group members face obstacles in coordination, sharing information, and acting collectively. ${ }^{129}$ Dispersing authority among group members creates a variety of collective action problems, including the possibilities of free-riding, ${ }^{130}$ cycling, ${ }^{131}$ and strategic behavior. ${ }^{132}$

These problems increase when the court appoints a lead plaintiff group consisting of group members with relatively small stakes. Although the group may have a large financial interest in the aggregate, the small individual stakes reduce the likelihood that group members will participate actively in the litigation

123. See, e.g., Packard v. Provident Nat'l Bank, 994 F.2d 1039, 1045 (3d Cir. 1993) ("It is well-settled that in a diversity-based class action, members of the class may not aggregate their claims in order to reach the requisite amount in controversy."); accord Zahn v. Int'l Paper Co., 414 U.S. 291, 301 (1973).

124. Indeed, the statute itself directs courts to consider its purposes. See Aronson v. McKesson HBOC, Inc., 79 F. Supp. 2d 1146, 1156 (N.D. Cal. 1999).

125. Greenberg v. Bear Stearns \& Co., 80 F. Supp. 2d 65, 70 (E.D.N.Y. 2000), citing CONF. REP., supra note 19.

126. See, e.g., In re Telxon Corp. Sec. Litig., 67 F. Supp. 2d 803, 814 (N.D. Ohio 1999).

127. See id. at 815 (detailing elements of statutory structure that reflect congressional desire to reduce agency costs and collective action problems and explaining that these concerns "permeate[] the statute" and are "apparent without resort to the legislative history").

128. See generally R. Chris Heck, Comment, Conflict and Aggregation: Appointing Institutional Investors as Sole Lead Plaintiffs under the PSLRA, 66 U. CHI. L. REV. 1199, 1219-21 (1999) (describing inefficiencies associated with decisionmaking by aggregate lead plaintiff group).

129. See id.

130. See, e.g., IAIN MCLEAn, PUBliC ChOICE: AN InTRODUCTION 11-12 (1987) (explaining freeriding problem as one in which group members are able to obtain a benefit (or avoid a cost) without paying for it). Increases in group size generally lead to an increase in free-riding. See MANCUR Olson, JR., The Logic of COllective ACtion: Public Goods AND THE THEOry of Groups 48 (1965).

131. See, e.g., Kenneth Arrow, Social Choice And Individual Values (1951) (identifying risk that voting cycling will interfere with the selection of the outcome enjoying the greatest support).

132. See Jeanne L. Schroeder, The End of the Market: A Psychoanalysis of Law and Economics, 112 HARV. L. REV. 483, 542-44 (1998) (describing various forms of strategic behavior). 
process. ${ }^{133}$ As the court explained in Zaltzman v. Manugistics Group, Inc. ${ }^{134}$ the likely result is a conglomeration of individuals who, because their "personal stakes in the outcome are smaller," lack the "incentive for zealous participation and interaction with class counsel." ${ }^{135}$

In the context of securities litigation, the appointment of a lead plaintiff group effectively transfers control from the investor to the lawyer. In virtually all cases, lawyers are responsible for assembling and managing lead plaintiff groups. Lawyers control group formation, choosing which investors to propose as group members and manipulating group membership at will. ${ }^{136}$ This enables lawyers to select for any combination of client characteristics, including passivity. ${ }^{137}$ Even where the court participates in the selection of group members, further management of the lead plaintiff group is left to the direction of the lawyers, who decide when to consult with the group, what information to provide, and so forth. ${ }^{138}$ This structure provides little potential for client monitoring. Indeed, in at least one reported case, an investor was not even advised that he was a member of the lead plaintiff group. ${ }^{139}$

Aggregation also undermines the most significant aspect of the lead plaintiff position: the authority to select and retain lead counsel. ${ }^{140}$ This authority is central to the lead plaintiff's ability to monitor the litigation. The PSLRA enables the lead plaintiff to monitor its lawyers by (1) reviewing lawyer qualifications and selecting appropriate counsel; (2) negotiating a fee structure that reduces

133. See, e.g., KOMESAR, supra note 8, at 68 (explaining how higher per capita stakes increase likelihood that group members will participate effectively).

134. No. S-98-1881, 1998 U.S. Dist. LEXIS 22867 (D. Md. Oct. 8, 1998).

135. Id. at *14-15 (explaining how the appointment of such a group "subverts" the statutory purpose of active involvement and attorney oversight).

136. See, e.g., In re Waste Management, Inc., Sec. Litig., No. H99-2183, 2000 U.S. Dist. LEXIS 9370, at $* 41-42$ (S.D. Tex. May 8, 2000) (describing criticism of WMPG group for proposing alternatively a group of 660 members, a 12-member "institutional group" and 11-member steering committee or a three-member executive committee); $i d$. at 52-53 (recounting contention that conglomeration of law firms was responsible for selecting proposed subgroups); Switzenbaum v. Orbital Sciences Corp., 187 F.R.D. 246, 250-51 (E.D. Va. 1999) (describing variable formulations of proposed lead plaintiff group, including attempts "to bootstrap members in and out of its leadership").

137. See Yousefi v. Lockheed Martin Corp., 70 F. Supp. 2d 1061, 1069 (C.D. Cal. 1999) ("[P]ermitting the group and its counsel to name representative lead plaintiffs would allow counsel to name nominally interested plaintiffs as a means of seizing control of the suit.").

138. Moreover, because the statute provides no basis for allocating group decisionmaking authority, group members are, as a practical matter, hampered from exercising active oversight. Are litigation decisions subject to majority vote? Does each member have one vote or are voting rights based on each investor's financial interest? How does the group resolve a deadlock? If group members have different preferences, do they vote, defer to counsel, or appeal to the court? Investors without a preexisting relationship are unlikely to resolve these issues, which effectively leaves decisionmaking in the control of plaintiffs' counsel.

139. See Amicus Brief of SEC at 3, Parnes v. Digital Lightwave, Inc., No. 99-11293 (11th Cir. Aug. 25, 1999), available at (visited Mar. 24, 2001) <http://securities.stanford.edu/briefs/digl/9911293 /990825sec.html> (explaining that one member of the lead plaintiff group "was not even apprised that he had been named as a group member until well after a settlement in the case was agreed to and submitted to the court for approval").

140. See, e.g., Gluck v. CellStar Corp., 976 F. Supp. 542, 550 (N.D. Tex. 1997) (describing provision authorizing lead plaintiff to select counsel as "a critical part of Congress's effort to transfer control of securities class actions from lawyers to investors"). 
agency costs and increases the lawyers' incentives to act in the best interests of the plaintiff class; and (3) continuing to supervise lawyer decisions throughout the litigation. A court that appoints a lead plaintiff group, however, effectively appoints the lawyer representing that group and authorizes the lawyer to select the group members. This result defeats the purpose of the PSLRA that the client choose counsel instead of counsel choosing the client. ${ }^{141}$

Moreover, reading the statutory text to require aggregation leads to an absurd result. Because the statute contains no limitations on the term "group," it provides no express authority for courts to limit group size arbitrarily. ${ }^{142}$ Absent such authority, however, the court would be unable to restrict groups of hundreds or even thousands of members. The statute would permit, or perhaps even force, the court to appoint the group with the largest aggregate holdings, regardless of size or number of members. Indeed, the entire plaintiff class could be joined into a single lead plaintiff group. ${ }^{143}$ To avoid such a result, judicial authority to limit the use of lead plaintiff groups where necessary to achieve the statutory objectives must be inferred.

The legislative history lends additional support to the argument that aggregation is not appropriate. ${ }^{144}$ The Network Associates opinion carefully examines the legislative history of the PSLRA and finds that all references to the lead plaintiff are couched in the singular. ${ }^{145}$ There is no suggestion that the lead plaintiff can consist of multiple investors or that Congress intended for the lead plaintiff to be an amalgamation. The House Conference report, for example, makes at least twelve references to the lead plaintiff, all in the singular. ${ }^{146}$

The legislative history further demonstrates congressional concern with client empowerment as a means to address the problems Congress identified with lawyer-driven litigation. ${ }^{147}$ A key indication that Congress viewed a group or committee as an inferior structure for monitoring plaintiffs' counsel is reflected

141. See CONF. REP., supra note 19 , at 6.

142. Cf. D'Hondt v. Digi Int'l Inc., No. 97-5 (JRT/RLE) 1997 U.S. Dist. LEXIS 17700, at*13 (D. Minn. Apr. 3, 1997) ("[A]n arbitrary limit on the number of proposed Lead Plaintiffs would be unrealistic, if not wholly counterproductive.").

143. See, e.g., Sakhrani v. Brightpoint, Inc., 78 F. Supp. 2d 845, 853 (S.D. Ind. 1999) (observing that some of the proposed lead plaintiff groups are themselves large enough to satisfy the Rule 23 requirements for a class action).

144. Even Justice Scalia, the Court's most ardent defender of textualism, permits the use of extrinsic evidence when literal application of the statute would lead to an absurd result. See Green v. Bock Laundry Mach. Co., 490 U.S. 504, 527-30 (1989) (Scalia, J., concurring) (distinguishing between the use of legislative history in general and its use to avoid an absurd result); see also William D. Popkin, An Internal Critique of Justice Scalia's Theory of Statutory Interpretation, 76 MINN. L. REV. 1133, 1155-59 (1992).

145. See In re Network Assocs., Inc., Sec. Litig., 76 F. Supp. 2d 1017, 1025 (N.D. Cal. 1999) (“[N]o reference whatsoever was made in the reports to multiple, unrelated individuals at the helm.").

146. See CONF. REP., supra note 19, at 33-35.

147. See, e.g., Aronson v. McKesson HBOC, Inc., 79 F. Supp. 2d 1146, 1154 (N.D. Cal. 1999) (finding narrow reading of group most "consistent with the legislative intent to increase client control over plaintiff's counsel"). 
in the evolution of the lead plaintiff provision from its statutory predecessors. ${ }^{148}$ The lead plaintiff group bears a strong resemblance to the plaintiff steering committee, a concept that was proposed in earlier versions of the statute but ultimately rejected in the PSLRA. ${ }^{149}$ A plausible reason that Congress substituted the lead plaintiff provision for the plaintiff steering committee is its concern that the group decisionmaking required by the latter would prove ineffective. ${ }^{150}$

The legislative history also reveals that Congress was particularly interested in encouraging institutional investors to serve as lead plaintiffs. ${ }^{151}$ Congress viewed institutional investors as having greater sophistication and ability to monitor as well as the substantial stakes that would make monitoring rational. ${ }^{152}$ The legislative history explains that the statutory presumption in favor of the investor with the largest interest in the case was designed to increase the likelihood that institutional investors would serve as lead plaintiffs. ${ }^{153}$ The use of lead plaintiff groups is inconsistent with this statutory objective. As the cases demonstrate, it is possible to create a sufficiently large group of individual investors such that the group's holdings, if aggregated, would exceed those of any institution. $^{154}$ Judicial acceptance of these groups thus reduces the likelihood that an institutional investor will be appointed as lead plaintiff.

It is also undesirable as a matter of policy for courts to accept aggregation and appoint large lead plaintiff groups. ${ }^{155}$ First, as indicated above, the possibility of aggregation creates undesirable incentives for would-be lead counsel.

148. Courts interpreting the lead plaintiff provision have paid surprisingly little attention to this evolution.

149. See, e.g., S. 240, 104th Cong., §§ 101(c), 103 (1995) (requiring appointment of guardian ad litem and steering committee for the plaintiff class); H.R. 10, 104th Cong., § 202(a) (1995) (providing for plaintiff steering committees); See also Janet Cooper Alexander, Rethinking Damages in Securities Class Actions, 48 STAN. L. REV. 1487, 1528-29 (1996) (proposing plaintiff's steering committees to "supervise class counsel and make those litigation and settlement decisions traditionally reserved to the client," on which institutional investors that opt into the class action would be required to participate).

150. See, e.g., Securities Litigation Reform: Hearings before the Subcommittee on Telecommunications and Finance of the House Committee on Energy and Commerce, 103d Cong., 2d Sess. 142, 144 (1994) (testimony of Arthur Miller, Professor of Law, Harvard University Law School) [hereinafter Testimony of Arthur Miller] (describing plaintiff steering committee as "a very big mistake" and a "godlike Greek chorus").

151. See, e.g., CONF. REP., supra note 19, at 34 (describing congressional desire to "encourage institutional investors to take a more active role in securities class action lawsuits"). See generally Heck, supra note 128, at 1204 (arguing that legislative history of the PSLRA shows that Congress intended it to encourage institutional investors to become lead plaintiffs).

152. See In re Lucent Techs. Sec. Litig., 194 F.R.D. 137, 151-52 (D.N.J. 2000) (describing congressional goal of institutional investor monitoring).

153. See S. REP., supra note 45, at 11 ("The Committee intends to increase the likelihood that institutional investors will serve as lead plaintiffs by requiring the court to presume that the member of the purported class with the largest financial stake in the relief sought is the "most adequate plaintiff."').

154. See, e.g., In re Waste Management, Inc., Sec. Litig., No. H-99-2183 (MH), 2000 U.S. Dist. LEXIS 9370, at *35 (S.D. Tex. May 8, 2000) (describing a motion by the Waste Management Plaintiffs Group, consisting of 660 individual investors, which claimed a larger aggregate loss than any other movant, including the State of Connecticut).

155. See Jill E. Fisch, The Scope of Private Securities Litigation: In Search of Liability Standards for Secondary Defendants, 99 COLUM. L. REV. 1293, 1312 (1999) (arguing that courts should consider legislative purpose and policy considerations in interpreting the federal securities laws). 
The efforts of some firms to create massive lead plaintiff groups to secure the lead counsel appointment are not socially productive. ${ }^{156}$ Most controversial is the practice employed by Weiss \& Yourman of paying the expenses of brokerage houses to send material to investors about pending lawsuits. ${ }^{157}$ The practice has been challenged as improper client solicitation, as well as inconsistent with the PSLRA. ${ }^{158}$ Whether or not it is technically legal, it raises serious ethical concerns. Courts have not restricted the practice yet, however, and Weiss \& Yourman has used it successfully to recruit investors to join its lead plaintiff groups. ${ }^{159}$

The SEC argued in Network Associates that the solicitation practice could have the beneficial effect of providing investors with notice of a pending action and the opportunity to seek appointment as lead plaintiff. ${ }^{160}$ The claim that investor solicitation effectively informs investors is, at best, naïve. An examination of the solicitation materials used in recent securities cases demonstrates that they provide investors with little more than instructions on how to join the lead plaintiff group. ${ }^{161}$ The solicitation materials include only limited information about the litigation process and, many times, lead to investor confusion. ${ }^{162}$ In several cases, investors recanted and withdrew from lead plaintiff groups, explaining to the court that the material they received misled them. ${ }^{163}$ Rather than

156. See Sakhrani v. Brightpoint, Inc., 78 F. Supp. 2d 845, 851 (S.D. Ind. 1999) (criticizing aggregation for creating an incentive for plaintiffs' lawyers to compete in assembling the largest lead plaintiff group).

157. See, e.g., Paul Elias, Both Sides Attack Twist in Stock Cases, RECORDER, Sept. 8, 1999, at 1 (describing solicitation practices).

158. See Seamans v. Aid Auto Stores, Inc., [2000 Transfer Binder] Fed. Sec. L. Rep. (CCH) II 90,902 , at 93,806 (E.D.N.Y. May 28, 2000) (describing the argument by a competing firm that the lead plaintiff motion should be denied because "it is tainted by the . . a attorneys' improper attempt to solicit individuals with enough shares to form a plaintiff group with the greatest financial stake in order to be appointed lead plaintiff"); NAPLG Opposition in Network Associates, supra note 74, at 153 (describing Weiss \& Yourman's mass mailings and reimbursement of broker mailing expenses as illegal and unethical client solicitation); Elias, supra note 157 (describing challenges in Network Assocs. and Landry's cases).

159. See Elias, supra note 157 (describing finding by Network Assocs. court that practice was neither illegal nor unethical and success of Weiss \& Yourman in using the practice to recruit investors).

160. See Network Amicus Brief, supra note 105, at 1053-54.

161. For example, as a Waste Management shareholder, I received a copy of the solicitation materials prepared by Weiss \& Yourman. The materials included a copy of the complaint, a one page letter, and a certification form. The letter stated that Weiss \& Yourman represents the plaintiff and numerous other shareholders, has significant experience, and has undertaken the litigation on a contingent fee basis. It instructed me to return the certification form if I wanted to join the group of lead plaintiffs. The material did not state that I would remain as a member of the plaintiff class if I did not send in the form. The certification form did not indicate that, by completing the form, I was agreeing to retain Weiss \& Yourman as my attorney. Finally, the material provided no details about the firm's qualifications or the structure of the contingency fee.

162. See, e.g., Sakhrani v. Brightpoint, Inc., 78 F. Supp. 2d 845, 851 (S.D. Ind. 1999) (describing evidence indicating that at least some investors who return the forms in response to these solicitations believe they are simply preserving their claims rather than volunteering to serve as lead plaintiff).

163. See, e.g., In re Network Assocs. Sec. Litig., 76 F. Supp. 2d 1017, 1032 (N.D. Cal. 1999) (describing how many of the investors who had supposedly agreed to join in a particular lead plaintiff group "recanted and sent in declarations ... explaining how they had been misled by the form"); In re Waste Management, Inc. Sec. Litig., No. H-99-2183 (MH), 2000 U.S. Dist. LEXIS 9370, at *61-62 (S.D. Tex. May 8, 2000) (stating that various investors, including an institutional investor claiming a loss of 
informing, investor solicitation seems to be having the effect of creating ambiguous, uninformed, and even unauthorized representation relationships. ${ }^{164}$ Moreover, these effects are not limited to cases in which investors are solicited through direct mailings. As the Lucent court explained, some plaintiffs' lawyers have also converted the statutorily mandated notice into a marketing tool "designed primarily to accumulate members of the class rather than to inform." 165

Second, aggregation, particularly in its most popular form, converts the selection of the lead plaintiff from an objective process into an unwieldy and easily manipulated procedure. The presumption in favor of the investor with the largest financial interest provides an objective standard for the court and limits the ability of counsel to control the selection of lead plaintiff. Once the court accepts the premise of a lead plaintiff group, however, it loses objectivity. The court must determine the appropriate group size. The court must decide whether to choose the group members independently or whether to appoint a subgroup from a larger aggregation of investors. The court also must consider whether to become involved in reviewing individual group member qualifications or whether to leave that decision to class counsel. And, finally, the court must evaluate the propriety of selecting and substituting group members.

If the court defers to counsel with respect to the selection of group members, it has effectively undermined the PSLRA's efforts to reduce lawyer control of the litigation. ${ }^{166}$ As the court in Brightpoint recognized, decisions that allow aggregation, and then select from competing subgroups assembled by counsel, create the same agency and collective action problems that led Congress to adopt the PSLRA. ${ }^{167}$ In addition, these decisions generate "a great deal of truly useless activity . . . and controversy." ${ }^{168}$

If, instead, the court actively evaluates the composition of the lead plaintiff group, ${ }^{169}$ it initiates an arbitrary and wasteful process. ${ }^{170}$ Significantly, the PSLRA instructs courts to select the lead plaintiff based on the size of its finan-

$\$ 17$ million, withdrew lead plaintiff certification forms as "unauthorized and obtained by misleading practices.")

164. In addition, the adversarial process is poorly suited to uncover instances of investor confusion. Because the ethical rules prohibit lawyers from communicating with a party represented by counsel, a firm risks sanction if it attempts to verify the bona fides of the claimed representations. See, e.g., Stearns v. Navigant Consulting, Inc., 89 F. Supp. 2d 1014 (N.D. Ill. Mar. 28, 2000) (warning the firm that it had narrowly avoided being disqualified as lead counsel for contacting investors purportedly represented by a competing firm for the purpose of clarifying their consent to representation).

165. In re Lucent Techs. Sec. Litig., 194 F.R.D. 137, 147 (D.N.J. 2000).

166. See, e.g., Schlagal v. Learning Tree Int'l., [1999 Transfer Binder] Fed. Sec. L. Rep. (CCH) It 90,435, at 91,968-72 (C.D. Cal. Mar. 17, 1999) (citing decisions in which courts have left the designation of a lead plaintiff subgroup to counsel).

167. See 78 F. Supp. 2 d at 853.

168. Id.

169. See, e.g., In re Nice Systems Sec. Litig., 188 F.R.D. 206 (D.N.J. 1999) (reducing the size of a proffered nine-member group by eliminating four members whose interests were disproportionately small).

170. The court is limited even in its ability to determine the appropriate group size. See, e.g., Eric A. Posner, The Regulation of Groups: The Influence of Legal and Nonlegal Sanctions On Collective Action, 63 U. CHI. L. REV. 133, 139 n.12 (1996) (describing vast and complex literature on group cooperation). 
cial interest in the case. ${ }^{171}$ Thus, the statute expressly specifies the selection criteria. ${ }^{172}$ A court that inquires into other lead plaintiff characteristics or imposes additional qualifications is substituting its judgment for that of Congress. ${ }^{173}$ Moreover, expanding the scope of the inquiry creates inappropriate collateral litigation. Finally, the risk that the lead plaintiff will be subjected to intrusive discovery or personal attack is likely to discourage investors, particularly institutional investors, from seeking to serve as lead plaintiffs. ${ }^{174}$

The foregoing analysis leads to the conclusion that courts should read the term "group" narrowly and refuse requests for aggregation. Even the common use of groups consisting of three to five unrelated investors is inconsistent with the statutory objectives and is likely to undermine the effectiveness of the lead plaintiff. Instead, the foregoing analysis indicates that courts should accept multiple investors as a lead plaintiff group only when those investors have a pre-existing relationship independent of the litigation and function as a single decisionmaking unit. Families, partnerships, and multiple investment funds under common management are examples of groups that fall within the statutory language. ${ }^{175}$ Other than these narrowly defined groups, courts should appoint only a single investor as lead plaintiff-the institution or individual with the largest financial interest in the case.

The recent decision in Waste Management ${ }^{176}$ demonstrates why it was necessary for Congress to include the term "group" in the statutory language and illustrates how that term should be applied. In that case, the State of Connecticut sought lead plaintiff status on behalf of six state pension funds. ${ }^{177}$ Because the funds were organized as independent legal entities, a competing lead plaintiff objected to their treatment as a single legal entity under the PSLRA. ${ }^{178}$ The court rejected this argument, finding that the funds were combined into a single pool for investment purposes and were operated under the direction of a single

171. But see Bank One Shareholders Class Actions, 96 F. Supp. 2d 780, 783-84 (N.D. Ill. 2000) (explaining that insistence by the presumptive lead plaintiff that its preferred counsel handle the case rather than the low bidder in the court's sealed bid auction would rebut the presumption that plaintiff was the "most adequate").

172. See Baan Amicus Brief, supra note 105, at 228 (arguing that Congress rejected the objective of fuller or more diverse representation in favor of the lead plaintiff with the largest financial interest).

173. See, e.g., Laborers Local 1298 Pension Fund v. Campbell Soup Co., [2000 Transfer Binder] Fed. Sec. L. Rep. (CCH) II 90,963, at 94,220 n.5 (D.N.J. May 17, 2000) (considering the possibility that the largest financial interest should be measured in relative rather than absolute terms).

174. See, e.g., Reply Memorandum of Connecticut Retirement Plans and Trust Funds in Support of its Appointment as Lead Plaintiff, at 10-11, In re Waste Management, Inc. Sec. Litig. (No. H-99-2183 (MH) (S.D. Tex. 1999) (describing attacks against Connecticut and a similar occurrence in the Telxon case).

175. See, e.g., Aronson v. McKesson HBOC, Inc., 79 F. Supp. 2d 1146, 1146 n.11 (N.D.Cal. 1999) (finding that New York City Pension funds, although technically separate entities, were one person for purposes of the PSLRA because they are under the jurisdiction of the New York City Comptroller's Office and represented by one in-house counsel, the New York Corporation Counsel).

176. In re Waste Management, Inc., Sec. Litig., No. H-99-2183 (MH), 2000 U.S. Dist. LEXIS 9370 (S.D. Tex. May 8, 2000).

177. See id. at $* 27$ n. 7 .

178. See id. at $* 32$. 
individual, the state Treasurer. ${ }^{179}$ Although the court concluded that as a result of this structure, the funds could be viewed as a single statutory person for purposes of the PSLRA, the court alternatively could have characterized the Connecticut funds as the type of narrow group authorized by the statute-one with a common decisionmaking structure and a practical and legal relationship independent of the litigation. These features distinguished the Connecticut funds from the other groups seeking appointment as lead plaintiff.

IV

\section{LEAD COUNSEL AUCTIONS}

\section{A. Introductory Issues-Litigation Developments and Selection of Counsel}

As indicated above, the lead counsel provision vests the lead plaintiff with the authority to select and retain lead counsel, subject to the approval of the court. Weiss and Beckerman envisioned this authority as enhancing the lead plaintiff's ability to monitor the litigation. ${ }^{180}$ Developments in the competition for and selection of the lead plaintiff, however, including lawyer-controlled formation of large lead plaintiff groups and judicial acceptance of aggregation, have created reasons for concern. Recent battles for the lead counsel position have confronted courts with allegations of lawyer misconduct, limited competition, and inadequate client control. This has led some courts to question whether the appointment of the lead plaintiff must automatically be linked to the selection of counsel.

Initially, plaintiffs' counsel used the lead plaintiff group as a tool of inclusion. Rather than compete for the lead counsel position and risk losing the appointment, firms combined their clients into a single lead plaintiff group, which then sought to have multiple firms appointed as co-lead counsel. ${ }^{181}$ Courts began to question the need for multiple lawyers, however, raising concerns about excessive legal fees and duplication of effort. ${ }^{182}$ Although plaintiffs' firms responded by assigning more specialized roles to the various lawyers, such as liaison counsel and coordinating counsel, these efforts failed to persuade courts that it was appropriate to designate multiple firms as lead counsel. ${ }^{183}$

Moreover, the attempts to secure the appointment of multiple law firms highlighted two of the weaknesses resulting from the use of a lead plaintiff

179. See id. at *89.

180. See Weiss \& Beckerman, supra note 16, at 2107.

181. See, e.g., Wenderhold v. Cylink Corp., 188 F.R.D. 577, 579 (N.D. Cal. 1999) (describing the effort by a seven-member proposed lead plaintiff group to appoint "a consortium of law firms to serve as co-lead counsel for the class"); Fisch, supra note 44, at 548 (describing the pattern in early decisions of appointing multiple class counsel).

182. See, e.g., In re Milestone Scientific Sec. Litig., 183 F.R.D. 404, 419-20 (D.N.J. 1998) (ordering the lead plaintiff to re-brief the issue of the propriety of multiple lead counsel).

183. See, e.g., Sherleigh Assocs. v. Windmere-Durable Holdings, Inc., 186 F.R.D. 669, 670 (S.D. Fla. 1999) (rejecting proposed representation by consortium of 10 law firms as not in the best interests of the plaintiff class). 
group. First, a group of unrelated investors represented by more than one lawyer has no inherent decisionmaking structure and, as a result, is poorly equipped to choose a single firm. Second, and more important, in most cases the lead plaintiff groups reflected continuing lawyer control over the litigation process. Lawyers recruited clients, assembled lead plaintiff groups, and structured the appointment of both lead plaintiff and lead counsel. As a result, it was unrealistic to view a lead plaintiff group as having selected its lawyer.

Rejection of lead plaintiff groups does not eliminate counsel selection problems. Courts have encountered problems with appointing institutional investors as lead plaintiffs. At least two courts have concluded that an institution cannot serve as a lead plaintiff in more than five cases during a three-year period, based on a statutory prohibition against professional plaintiffs. ${ }^{184}$ In addition, allegations of "pay to play" have been made in several cases. In Cendant, for example, a competing lead plaintiff group argued that the CalPERS group, which consisted of three public pension funds, should not be appointed lead plaintiff because its counsel had made a substantial contribution to the campaign of the New York State Comptroller. ${ }^{185}$ Although the Cendant court found no improper conduct, allegations that institutional investors will select a law firm on the basis of political contributions undermine judicial willingness to trust the lead plaintiff's retention decision. ${ }^{186}$

Judicial concerns about lawyer control of the client increase in cases in which institutional investors are not involved. A court may be troubled by the prospect of allowing an individual investor to select counsel on behalf of the plaintiff class and concerned about the ability of an individual to withstand lawyer control over the litigation. ${ }^{187}$ As the court explained in Cylink, the "[1]ead plaintiff, as an individual, almost certainly does not have the expertise and resources of a large institutional investor. His ability to select and monitor the conduct of class counsel is, therefore, inherently less than that of the ideal lead plaintiff." "188

Concerns about mudslinging and excessive lawyer control are united in recent cases involving solicitation of investors by plaintiffs' firms. In Network Associates, Waste Management, and other cases, some firms conducted direct

184. See In re Telxon Corp. Sec. Litig., 67 F. Supp. 2d 803, 819-22 (N.D. Ohio 1999); Aronson v. McKesson HBOC, Inc., 79 F. Supp. 2d 1146, 1156-57 (N.D. Cal. 1999). These decisions were based on the statutory restriction on professional plaintiffs found in 15 U.S.C. § 78u-4(a)(e)(vi) (Supp. IV 1998). See Telxon, 67 F. Supp. 2d at 820. But see In re Network Assocs. Sec. Litig., 76 F. Supp. 2d 1017, 1030 (N.D. Cal. 1999) (rejecting the argument that the professional plaintiff restriction applies to institutional investors).

185. See In re Cendant Corp. Litig., 182 F.R.D. 144, 148-49 (D.N.J. 1998).

186. See id. at 152 (explaining that, although the "pay-to-play" charges were not proven, "the auction is salutary because it removes any speculative doubt about that issue").

187. The experience of lead plaintiff Charles Chalmers in Digital Lightwave demonstrates the reason for this concern. See supra note 139 and accompanying text. But see Penny Arevalo, In Securities Litigation Cases, Judges are Proactively Selecting Plaintiffs, Counsel, CORP. LEGAL TIMES, July 2000, at 98 (describing lead plaintiff Robert Vatuone in Network Associates as being "very comfortable reading legal documents, negotiating and telling other lawyers what to do").

188. Wenderhold v. Cylink Corp., 188 F.R.D. 577, 587 (N.D. Cal. 1999). 
mailings or used brokerage firms to distribute litigation information to stockholders for the purpose of recruiting lead plaintiff group members. ${ }^{189}$ Other would-be lead counsel subsequently attacked these contacts as misleading, unethical, and felonious. Although courts have generally rejected these charges, and the SEC filed a brief in Network Associates defending the practice, ${ }^{190}$ courts are reasonably concerned about appointing counsel that has engaged in questionable conduct. ${ }^{191}$ Moreover, it is undesirable to select counsel through a procedure that encourages questionable solicitation practices.

\section{B. A Possible Solution: Lead Counsel Auctions}

The developments described above, coupled with preexisting judicial dissatisfaction with the selection of counsel and determination of attorneys' fees in class action litigation, have led courts to search for a better alternative. One of the more creative solutions is the use of a sealed bid auction. ${ }^{192}$ Under this model, firms seeking appointment as lead counsel submit bids to the court proposing a fee structure for conducting the litigation. ${ }^{193}$ The court uses the bids, and any other information it considers relevant, to select lead counsel. By selecting a "winning" bid, the court simultaneously selects lead counsel and determines counsel's fee. ${ }^{194}$

Although an obvious advantage of lead counsel auctions is their potential to reduce the cost of litigation, ${ }^{195}$ courts that have experimented with auctions in

189. See supra notes $153-165$ and accompanying text.

190. See Network Amicus Brief, supra note 105.

191. See In re Network Assocs. Sec. Litig., 76 F. Supp. 2d 1017, 1033-34 (N.D. Cal. 1999) (identifying the Digital Lightwave "imbroglio" as a sufficient concern to cause the court to require the lead plaintiff to reopen its consideration of counsel).

192. Cases under the PSLRA in which the court has ordered a lead counsel auction include In re Bank One Shareholders Class Actions, 96 F. Supp. 2 d 780 (N.D. Ill. 2000); In re Lucent Techs., Inc. Sec. Litig., 194 F.R.D. 137 (D.N.J. 2000); Sherleigh Assocs. v. Windmere-Durable Holdings, Inc., 184 F.R.D. 688 (S.D. Fla. 1999); Wenderhold v. Cylink Corp., 188 F.R.D. 577 (N.D. Cal. 1999); In re Cendant Corp. Litig., 182 F.R.D. 144 (D.N.J. 1998). A few courts have also ordered lead counsel auctions in antitrust class actions. See In re Amino Acid Lysine Antitrust Litig., 918 F. Supp. 1190 (N.D. Ill. 1996); Order, April 20, 2000, In re Auction Houses Antitrust Litig., No. 00 Civ. 0648 LAK, 2000 WL 1864036 (S.D.N.Y. Dec. 20, 2000) [hereinafter Auction Houses Order].

193. Network Associates used a variation of this process. The lead plaintiff was ordered to select counsel by conducting a sealed bid auction and to submit his top two choices to the court for approval. The process resulted in Mr. Vatuone selecting a different firm from those that had initially represented him in the case. See In re Network Assocs. Sec. Litig., 76 F. Supp. 2d 1017, 1019 (N.D. Cal. 1999) (describing Vatuone as represented by the law firms of Ruby \& Schofield and Manis Faulkner \& Morgan); Order Appointing Class Counsel, supra note 65 (stating court's approval of the firm of Lieff, Cabraser, Heimann \& Bernstein as class counsel).

194. The court in Cendant allowed the lead plaintiffs' preferred counsel to match the winning bid. See Cendant, 182 F.R.D. at 151. The firms chose to do so. See In re Cendant Corp. Prides Litig., 51 F. Supp. 2d 537, 539 (D.N.J. 1999). As a result, the auction in Cendant determined the fee award, but did not select lead counsel. See Sherleigh Assocs., 184 F.R.D. at 699 (rejecting the request for a similar "right of first refusal"); see also In re Bank One Shareholders Class Actions, 96 F. Supp. 2d 780, 789 (N.D. Ill. 2000) (allowing lead plaintiff's original counsel to participate as co-counsel with low bidder but in a secondary role, if that arrangement were negotiated on a basis acceptable to both firms).

195. See Remarks of C. Boyden Gray, Fees in the High Stakes Litigation of Class Actions and Suits by Governmental Agencies, Excessive Legal Fees: Protecting Unsophisticated Consumers, Class Ac- 
securities litigation seem to be motivated by the possibility that an auction will provide a more objective way of selecting lead counsel and a better way of determining an appropriate fee award. As Judge Walker explained in Oracle, in which he pioneered the use of the lead counsel auction, the purpose of the auction was to replicate a market process for the selection and compensation of lead counsel. ${ }^{196}$ Similarly, the court in Sherleigh Associates explained that an auction was consistent with several objectives of the PSLRA, including avoiding the race to the courthouse and allowing the court to address the agency costs of the class action by choosing a compensation structure designed to align the interests of the class and counsel. ${ }^{197}$

Several courts have refined the auction process in an effort to improve on Judge Walker's original model. For example, the court's order in Oracle gave counsel little guidance with respect to the bid structure; the court simply ordered the bids to correspond to the percentage-of-recovery method of compensation and indicated that counsel could vary the percentage according to specified contingencies. ${ }^{198}$ Subsequent auction orders have included litigation milepost grids that break the litigation, by blocks, into discrete stages and amounts of recovery. ${ }^{199}$ Bidding firms are instructed to submit a proposed fee for each block of the grid. ${ }^{200}$ Sometimes the court also instructs firms to indicate how costs will be deducted from the fee award. ${ }^{201}$

Courts have demanded an increasing quantity of information from bidders in addition to bid price and structure. The Oracle court ordered lead counsel applicants to submit information regarding their qualifications. ${ }^{202}$ In later cases, bidders have been asked to describe their qualifications, experience, malpractice coverage, and willingness to post a completion bond. ${ }^{203}$ Firms have been asked to demonstrate that they evaluated the case and to specify the range and likelihood of recovery. ${ }^{204}$ The Sherleigh Associates court even asked firms to explain their chosen bid structure in terms of incentives and agency costs. ${ }^{205}$

tion Members, and Taxpayers/Citizens, U.S. Chamber of Commerce (May 25, 2000) (describing the potential for lead counsel auctions to reduce excessive plaintiffs' attorneys fees).

196. See In re Oracle Sec. Litig., 131 F.R.D. 688, 693 n.12 (N.D. Cal. 1990) (explaining that judicial selection of counsel should "make use of the mechanisms of a competitive market").

197. See Sherleigh Assocs., 184 F.R.D. at 694-95.

198. See Oracle, 131 F.R.D. at 697.

199. See, e.g., In re Lucent Techs. Sec. Litig., 194 F.R.D. 137, 157 (D.N.J. 2000); Sherleigh Assocs., 184 F.R.D. at 698; Wenderhold v. Cylink Corp., 188 F.R.D. 577, 588 (N.D. Cal. 1999).

200. The use of grids facilitates comparison of bids. See In re Bank One Shareholders Class Actions, 96 F. Supp. 2d 780, 786-87 (N.D. Ill. 2000), in which the court, which did not use such a grid, explained the difficulty of comparing bids with different recovery structures and varying "crossover points."

201. See, e.g., Sherleigh Assocs., 184 F.R.D. at 697. See also Cylink, 189 F.R.D. at 572-73 (rejecting the submitted bid for seeking reimbursement of litigation expenses in addition to attorneys' fees).

202. See Oracle, 131 F.R.D. at 697.

203. See, e.g., Lucent, 194 F.R.D. at 157; Sherleigh Assocs., 184 F.R.D. at 696.

204. See, e.g., Lucent, 194 F.R.D. at 157.

205. See Sherleigh Assocs., 184 F.R.D. at 696. 
Finally, many courts have limited the disclosure of information in connection with the submission of bids. ${ }^{206}$ The Oracle order required firms to prepare their bids independently and prohibited them from conferring with other firms or revealing their bids prior to filing with the court. ${ }^{207}$ In the opinion announcing the appointment of counsel, however, Judge Walker disclosed both the identities of the bidders and details of the submitted bids. ${ }^{208}$ In contrast, the court in Cendant disclosed no information about the auction until a proposed settlement had been submitted to the court - almost nineteen months after the auction was conducted-except to announce that the lead plaintiffs' chosen firms had agreed to match the winning bids. At that point, the court released a heavily redacted description of the bids, without disclosing the identities of the bidders. ${ }^{209}$ Similarly, the court in Sherleigh Associates explained that its order analyzing the submitted bids would be filed under seal during the pendency of the litigation. ${ }^{210}$ In addition, although the court in Cendant allowed firms to submit bids jointly, the more recent auction orders have forbidden joint bids. ${ }^{211}$ It is unclear whether this development was motivated by a desire to increase competition or to avoid collusion.

\section{Implementation of Lead Counsel Auctions-Practical Considerations}

Lead counsel auctions remain a work in progress. Judicial experience with the auction process is limited, and few cases utilizing an auction have progressed to a stage in which it is possible to evaluate the result. Nonetheless, the initial experience suggests a variety of practical problems with the design and implementation of lead counsel auctions that, to date, have not been adequately addressed by the courts. The fundamental question is whether it is appropriate to select counsel by auction. Although, as indicated above, auctions can allow courts to avoid a number of problems associated with the selection of class counsel, the characteristic feature of an auction is the comparison of bids on the basis of price. ${ }^{212}$ For bids to provide the court with an objective basis on which

206. But see In re Bank One Shareholders Class Actions, 96 F. Supp. 2d 780, 785-87 (N.D. Ill. 2000) (disclosing full information on firm identities and bid details in connection with selection decision).

207. See Oracle, 131 F.R.D. at 697.

208. See In re Oracle Sec. Litig., 132 F.R.D. 538, 539-41 (N.D. Cal. 1990). Judge Walker made a similar disclosure in Cylink. See Wenderhold v. Cylink Corp., 191 F.R.D. 600, 603-05 (N.D. Cal. 2000); Cylink, 189 F.R.D. 570, 574-75 (N.D. Cal. 1999).

209. See In re Cendant Corp. Litig., 191 F.R.D. 387 (D.N.J. 1998) (partially unsealed by the court on Apr. 7, 2000).

210. See Sherleigh Assocs. v. Windmere-Durable Holdings, Inc., 186 F.R.D. 669, 671 (S.D. Fla. 1999); see also Sherleigh Assocs., 184 F.R.D. at 698 (stating that the "bids may be permanently sealed or redacted thereafter to protect proprietary information").

211. See, e.g., In re Lucent Techs. Sec. Litig., 194 F.R.D. 137, 157 (D.N.J. 2000) (stating that joint proposals will not be considered); Sherleigh Assocs., 184 F.R.D. at 695.

212. See Paul R. Milgrom, Auction Theory, in ADVANCES IN ECONOMIC THEORY FIFTH WORLD CONGRESS 2 (Truman F. Bewley ed., 1987). 
to distinguish among counsel, the court's determination must focus primarily on price. $^{213}$

As a result, contrary to Judge Walker's claim in Oracle, lead counsel auctions do not replicate the market process for selection of counsel. Clients in the market for legal services do not choose their lawyer based solely on price. Indeed, the depth of the market for legal services, with its wide variation in billing rates, demonstrates the importance of non-price considerations. As in many markets, lawyer price and quality are often directly related. Those lawyers who offer higher quality legal services are able to command a higher price for their services. Less qualified lawyers charge a lower price. Lawyer quality is an important component of the selection process because a higher quality lawyer maximizes the client's expected recovery by increasing the likelihood of recovery, the amount of recovery, or both. Thus, although defendants would presumably favor an auction that relies primarily on price to select plaintiffs' counsel, the interests of the class require the court to consider lawyer quality and to reject an auction procedure that focuses exclusively on price.

Accordingly, the court must evaluate the quality of prospective lead counsel. It is unclear whether courts are equipped to make such an evaluation. Courts have had little success evaluating quality in the auction context. In Oracle, Judge Walker attempted to evaluate firm quality but found that the material submitted by the bidding firms was not helpful in assessing firm quality; he concluded that it was "impossible objectively to distinguish among these firms in terms of their background, experience and legal abilities." ${ }^{214}$ As a result, Judge Walker's decision was made exclusively on the basis of price, despite the illogic of that approach. ${ }^{215}$

The court's analysis in Cendant, in contrast, claimed to take quality considerations into account. ${ }^{216}$ The court explicitly rejected some firms on the basis of quality factors, concluding for example that several bidders had not demonstrated sufficient securities trial experience. ${ }^{217}$ The court did not indicate, however, either why trial experience was the key consideration in evaluating quality or how the court reached the conclusion that the experience of these bidders was deficient. Nor did the court's inquiry, at least as revealed in its opinion, seem to consider firm reputation, quality of investigation, or any other quality

213. The decision in In re Bank One Shareholders Class Actions, 96 F. Supp. 2d 780, 788 (N.D. Ill. 2000), illustrates such an analysis. The court compared the competing bids solely on the basis of price and, after presumptively selecting the winning firm, reviewed the firm's qualifications and determined that it qualified as a "responsible bidder." Id. at 788-89.

214. In re Oracle Sec. Litig., 132 F.R.D. 538, 542 (N.D. Cal. 1990).

215. See id. at $542 \mathrm{n} .10$ (explaining that "none of the bidders has demonstrated qualitative distinctions sufficient to outweigh price considerations").

216. See In re Cendant Corp. Litig., 191 F.R.D. 387, 390 (D.N.J. 2000) (explaining that the most important criteria to the court in evaluating bids were litigation experience, fiscal ability, and the proposed fee schedule).

217. See id. at 388, 391. 
factors. ${ }^{218}$ Although trial experience may be an important consideration, given that securities class actions rarely proceed to trial, trial experience would probably not be paramount in a client's selection decision. Moreover, an otherwise qualified firm could always obtain the services of specialized trial counsel to deal with the contingency of a trial.

The court in Sherleigh Associates apparently viewed the Cendant court's consideration of quality as limited, describing the Cendant auction as based on price alone. ${ }^{219}$ In Sherleigh Associates, Judge Lenard claimed that, unlike the Cendant court, she had constructed an auction with both qualitative and price considerations. ${ }^{220}$ Judge Lenard instructed counsel that she would evaluate bid proposals on a price-quality continuum with quality considerations, including the bid structure, the firm's experience in securities litigation, the firm's qualifications to complete the work, and evidence that the firm had evaluated the case. ${ }^{221}$ The court failed, however, to provide any criteria indicating how these factors would be evaluated. If a court does not specify precisely which factors demonstrate firm quality, it can use quality factors to rationalize the selection of whichever firm it chooses.

The court's analysis in Wenderhold v. Cylink ${ }^{222}$ illustrates this problem. Although a bidder might reasonably assume that firm size, a local office, and litigation experience within the circuit would be quality factors that weighed in its favor, the Cylink court concluded that precisely the opposite was true. Bidder Weiss \& Yourman argued that its larger size, West Coast office, and securities litigation experience within the circuit were qualitative advantages. ${ }^{223}$ Instead, Judge Walker concluded that the quality analysis favored bidder Innelli \& Molder because the firm's smaller size, absence of a West Coast office, and absence of litigation experience in the circuit would give it greater incentives to succeed. ${ }^{224}$ A court's assessment of firm quality seems arbitrary when a firm's small size or lack of litigation experience can be either a benefit or a detriment for purposes of quality evaluation.

As these cases demonstrate, evaluation of firm quality is difficult. The inherent difficulty for courts in evaluating firm quality makes it difficult for high quality firms to distinguish themselves so as to justify the higher price they command for their legal services. The knowledge that they cannot compete with lower quality firms on the basis of price may cause high quality firms to drop out of an auction they cannot win, rather than needlessly incur the costs of participation. This creates a potential "lemons" problem, in which lower qual-

218. The court did reject one bidder for having accused a lead plaintiff of wrongdoing. See id. at 391.

219. See Sherleigh Assocs. v. Windmere-Durable Holdings, Inc., 186 F.R.D. 669, 671 (S.D. Fla. 1999).

220. See id.

221. See Sherleigh Assocs., 184 F.R.D. 688, 696 (S.D. Fla. 1999).

222. 191 F.R.D. 600 (N.D. Cal. 2000).

223. See id. at 602.

224. See id. at 602-03. 
ity lawyers are disproportionately represented in the pool of bidding firms. ${ }^{225}$ In addition, the subjective nature of the quality evaluation threatens to undermine the potential objectivity of the auction process. ${ }^{226}$ Alternatively, a court may place undue emphasis on the lowest bid and use quality considerations in an effort to justify a choice that has been made primarily on the basis of price.

Even if a court restricts its analysis to bid price, the task of identifying the winning bid is not trivial. As auctions have gotten more sophisticated, the bids have become increasingly complex. Courts require firms to submit bids that specify recovery rates that vary depending on the occurrence of various contingencies, including the stage at which the litigation is terminated and the amount of damages recovered. ${ }^{227}$ Unlike a typical auction, in which the auctioneer can readily calculate which bid provides the best price, in a lead counsel auction, the court must predict the course of the litigation and estimate the likely recovery to determine the amount of each bid and compare competing bids. ${ }^{228}$

The complexity of the bids stems, in part, from judicial recognition that bid structure, in addition to bid price, is important. Different bid structures create a variety of incentive problems due to the conflict between the interests of counsel and the interests of the plaintiff class. ${ }^{229}$ Accordingly, a court must consider the incentive effects created by each bid structure and how those effects are likely to influence the conduct of the litigation and the recovery to the plaintiff class.

Unfortunately, each structure has advantages and disadvantages. For example, a bid structure in which counsel receives a declining percentage-ofrecovery encourages an early settlement of the case, which may shortchange class members and provide additional compensation to counsel. This effect is enhanced if the bid places a cap on costs or requires counsel to pay costs out of the fee award. Also, at high levels of recovery, a declining percentage fee structure does not align counsel's interests with those of the class and, therefore, may provide insufficient incentive for counsel to pursue recovery beyond a certain level. ${ }^{230}$ At the extreme, a fee structure that includes a cap on attorneys' fees eliminates any incentive for counsel to pursue a recovery beyond that point. ${ }^{231}$ On the other hand, as Judge Walker observed, the attorney effort necessary to obtain increased levels of recovery typically does not increase at the same rate

225. See, e.g., George Akerlof, The Market for "Lemons": Quality, Uncertainty and the Market Mechanism, 84 QUART. J. ECON. 488 (1970) (describing lemons problem); see also Niebler, supra note 34, at 777-78 (applying "lemons" analysis to lead counsel auctions).

226. It may also be argued that judicial evaluation of firm quality interferes with the court's neutrality.

227. See, e.g., In re Lucent Techs. Sec. Litig., 194 F.R.D. 137, 157 (D.N.J. 2000).

228. See Affidavit of Jill E. Fisch, May 3, 2000, at 9-11, In re Auction Houses Antitrust Litig., No. 00 Civ. 0648, 2000 U.S. Dist. LEXIS 18325 (S.D.N.Y. Dec. 20 2000) [hereinafter Auction Houses Affidavit] (demonstrating how bid structures require the court to estimate the likely recovery to determine which bid offers the best price).

229. See Niebler, supra note 34 , at 29-30.

230. See id.

231. A cap is practically equivalent to a percentage-of-recovery that declines to zero. 
as the level of recovery. ${ }^{232}$ A declining percentage-of-recovery requires counsel to share those economies with the plaintiff class. ${ }^{233}$

An alternative is to award counsel an increasing percentage-of-recovery. In theory, this structure should reduce counsel's motivation to sell out cheaply. Moreover, increasing counsel's motivation to pursue a larger recovery benefits the class as long as counsel's percentage-of-recovery remains below $100 \%$. Nonetheless, this structure can produce extremely large fees in cases involving large recoveries, causing most courts to view increasing percentage bid structures with skepticism. ${ }^{234}$ Because the court does not know the amount of recovery at the time it selects counsel, it is difficult for the court to commit to a proposed fee that might be large in terms of percentage and/or dollar amount.

Review of the few cases in which lead counsel auctions have been used provides some examples of poor judicial selection, suggesting that courts cannot easily predict the potential adverse consequences of a proposed fee structure. For example, in selecting counsel in Oracle, Judge Walker identified a fee discount for early settlement and a cap on litigation expenses as important factors. ${ }^{235}$ Subsequently, the case settled precisely at the point at which class counsel hit the cap on expenses. ${ }^{236}$ Moreover, the case did not settle within the window that would have provided a discounted fee award. ${ }^{237}$ Recovery to the class was approximately $24.5 \%$ of the claimed damages, a rate that at least one commentator has described as a benchmark settlement rate in securities fraud class actions. ${ }^{238}$

The bid structure selected in In re Amino Acid Lysine Antitrust Litigation ${ }^{239}$ was even more problematic. The winning bid proposed a fee structure in which counsel received a declining percentage-of-recovery up to $\$ 25$ million and no percentage of amounts recovered over $\$ 25$ million. ${ }^{240}$ The case then settled almost immediately, by some accounts for exactly $\$ 25$ million. ${ }^{241}$ Clearly the fee structure gave counsel no incentive to hold out for a recovery greater than $\$ 25$

232. See Wenderhold v. Cylink Corp., 189 F.R.D. 570,572 (N.D. Cal. 1999).

233. See id.

234. See Niebler, supra note 34, at 783-84 (describing judicial preference for declining marginal contingency fees); $i d$. at 790 (explaining that courts have viewed increasing percentage fee arrangements with "extreme hostility").

235. See In re Oracle Sec. Litig., 132 F.R.D. 538, 542, 545 (N.D. Cal. 1990).

236. See Coffee Declaration, supra note 39, at 3 (describing the settlement of Oracle as occurring "at exactly the point at which the Lowey firm hit the ceiling on its expense reimbursement proposal").

237. See id.

238. See Janet Cooper Alexander, Do the Merits Matter? A Study of Settlements in Securities Class Actions, 43 STAN. L. REV. 497, 517 (1991).

239. 918 F. Supp. 1190 (N.D. Ill. 1996).

240. See Coffee Declaration, supra note 39 , at 4.

241. See id. But see Robert A. Swift, Attorney, Columnist Tangle over Bidding Process, NAT'L L.J., Oct. 12, 1998, at A20 (stating that the civil case settled for almost $\$ 50$ million); Archer Daniels to settle lawsuits for \$65 million; Company was accused of hiding price fixing, BALT. SUN, Sept. 28, 1996, at 20C (stating that Archer Daniels Midland agreed to pay $\$ 30$ million to settle the class action by investors). 
million; a higher recovery would have yielded no increase in the fee award. ${ }^{242}$ Moreover, the rapid settlement, occurring merely two months after the cases were consolidated, ${ }^{243}$ and the relatively low recovery in comparison to the criminal fine ${ }^{244}$ indicate that the court's selection of the winning bid was probably based on an erroneously low estimation of the potential recovery.

In a lead counsel auction conducted in an antitrust case, not a securities case, the court in In re Auction Houses Antitrust Litigation sought to design an auction structure that would eliminate the incentive for an early, cheap settlement. ${ }^{245}$ Modifying Andrew Niebler's proposal, ${ }^{246}$ the court initially requested counsel to submit bids according to a three-tiered structure in which the plaintiff class would receive the first tier of the recovery, counsel would receive the second tier, and any additional recovery would be split between the class and counsel in a three-to-one ratio. ${ }^{247}$ The court ordered prospective lead counsel to bid by specifying the proposed size of the first two tiers. ${ }^{248}$ Ultimately, perhaps in recognition of the deficiencies presented by its structure and the potential difficulties in bid evaluation, ${ }^{249}$ the court modified the auction structure to produce a simpler model in which plaintiffs' counsel would be compensated at a rate of twenty-five percent, but the plaintiff class would receive $100 \%$ of some initial recovery threshold before attorneys' fees would be applied. ${ }^{250}$ Bidding firms were asked to specify the initial recovery threshold. Although this modification simplified the process of evaluating competing bids, from the firm's perspective, it resulted in a structure that was substantially similar to the standard benchmark fee award, ${ }^{251}$ with the attendant incentive problems identified in Niebler's article. ${ }^{252}$

Finally, the court in Cendant ${ }^{253}$ accepted a bid that provided for a higher fee award than plaintiffs' counsel would have received under the retainer agreement negotiated by the New York City Pension Funds. In papers challenging class counsel's request for the fee set by the lead counsel auction, the New York

242. This issue was apparently not of concern to Judge Shadur, who subsequently indicated his receptiveness toward fee caps in In re Bank One Shareholders Class Actions, 96 F. Supp. 2d 780 (N.D. Ill. 2000). See also id. at 787 (selecting bid that provided a cap of $\$ 2.75$ million on total fees).

243. See id.

244. See, e.g., Angela Wissman, ADM Execs Nailed on Price-Fixing, May Do Time; Government Gets Watershed Convictions, But Company Still Dominates Lysine Market, ILl. LEGAL TiMES, Oct. 1998, at 1 (describing ADM's payment of record $\$ 100$ million criminal fine for price-fixing).

245. See In re Auction Houses Antitrust Litig., No. 00 Civ. 0648, 2000 U.S. Dist. LEXIS 18325

(S.D.N.Y. Dec. 20, 2000).

246. See Niebler, supra note 34 , at 821-30.

247. See Auction Houses Order, supra note 192 (describing terms of auction).

248. See id.

249. See Auction Houses Affidavit, supra note 228 (identifying problems with proposed bid structure).

250. See Auction Houses Order, supra note 192 (altering terms of the previous bidding structure).

251. The modified fee structure could be characterized as an increasing percentage-of-recovery fee with an initial rate of zero.

252. Alternatively, the modified structure could be characterized as an increasing percentage-ofrecovery fee with an initial rate of zero.

253. 191 F.R.D. 387 (D.N.J. 1998) (partially unsealed by the court on Apr. 7, 2000). 
City Pension Funds asserted that the bid chosen by the court provided for a fee award that was $\$ 76$ million higher than the result produced under the retainer agreement and yielded a fee of $\$ 10,861$ per hour for class counsel. ${ }^{254}$

The difficulties in evaluating the most appropriate fee structure suggest that courts should exercise caution in articulating a preference. ${ }^{255}$ If a court does not state a preference, however, and accepts bids that vary in structure, the court, as auctioneer, is comparing incomparables-apples and oranges-to determine the best bid.

In addition, a court that accepts bids that vary along multiple dimensionsfor example, price, bid structure, and firm quality-must determine how to weigh the different facets of the bids. It is possible to evaluate bids according to multiple criteria. The bids submitted by would-be government contractors are subject to scoring on the basis of both price and quality factors. ${ }^{256}$ This type of scoring is vastly different, however, from the ad hoc treatment of quality and bid structure evidenced by the lead counsel auction opinions published to date.

Although Judge Walker has defended lead counsel auctions because they allow the court to determine the fee award at the outset of the case, ${ }^{257}$ the task of comparing bids is hampered by the limited information available to the court at that time. The court must determine the likely recovery and predict the process by which that recovery will be achieved. The court must then evaluate each bid against those predictions to determine how the proposed structure will affect counsel's ability to achieve the predicted outcome. ${ }^{258}$ The auction requires the court to make these predictions at the outset of the case, before discovery reveals the facts and before motion practice uncovers the legal issues. Accordingly, the court has extremely limited information on the probability, amount, and range of possible recovery.

In contrast, if the court decides on the appropriate fee award at the conclusion of the case, the court can assess the amount and the quality of counsel's work effort. Moreover, although the court may not have complete information on the merits of the case, particularly if the case is resolved by settlement, the court is likely to have a better sense of the strength of the case and the degree

254. See Daniel Wise, NYC Moves to Slash Cendant Fees, LEGAL InTELLIGENCER, June 2, 2000, at 4 (describing the challenge to the fee award). The court subsequently adhered to the fee determined by the auction. See In re Cendant Corp. Sec. Litig., 109 F. Supp. 2d 285, 306 (D.N.J. 2000).

255. Compare John C. Coffee, Jr., Securities Class Auctions, NAT'L L.J., Sept. 14, 1998, at B6 ("Courts have assumed too glibly that they know which bid is best") with Wenderhold v. Cylink Corp., 191 F.R.D. 600, 602 (N.D. Cal. 2000) (adopting the "twin principles that the ratio of fees and expenses should decline as recovery increases and increase as the litigation progresses").

256. See, e.g., Yeon-Koo Chee, Design Competition Through Multidimensional Auctions, 24 RAND. J. ECON. 668, 668-69 (1993) (describing the "elaborate scoring system" used by the Department of Defense to evaluate source bids based on quality and price factors).

257. See Remarks of Judge Vaughn Walker, Fees in the High Stakes Litigation of Class Actions and Suits by Governmental Agencies, Excessive Legal Fees: Protecting Unsophisticated Consumers, Class Action Members, and Taxpayers/Citizens, U.S. Chamber of Commerce (May 25, 2000) (arguing that auctions are valuable because they determine the fee award ex ante).

258. Judge Shadur's opinion in In re Bank One Shareholders Class Actions, 96 F. Supp. 2d 780 (N.D. Ill. 2000), contains the most detailed analysis of this process. 
of risk associated with the litigation. Most important, by reserving its determination of the appropriate fee award until the conclusion of the case, the court can address many of the incentive problems previously identified. If the court believes that counsel has successfully piggybacked on government enforcement efforts, it can use the lodestar structure to compensate counsel for counsel's actual efforts. ${ }^{259}$ A court can also address the concern that counsel will run up excessive hours by limiting the fee to a percentage of the recovery. Moreover, so long as the court has the flexibility to use either compensation method, counsel's incentive to make decisions contrary to the interests of the plaintiff class, such as a collusive early settlement, will be minimized. ${ }^{260}$

The plaintiff class also is exposed to substantial risk if the court mistakenly selects as counsel a firm that has made an unrealistically low bid. Although ethical considerations would presumably preclude the firm from abandoning the representation, a firm is unlikely to continue to invest resources that it does not expect to recover. ${ }^{261}$ Moreover, defendants may take advantage of the auction selection process by resisting early and reasonable attempts to resolve the case in an effort to disrupt counsel's anticipated cost structure. ${ }^{262}$

Although counsel may be better positioned to estimate the expected recovery than the court, counsel, too, lacks complete information at the outset of the case. $^{263}$ This creates an additional difficulty for a prospective bidder. Where bidders bid for an item of unknown value, an auction model known as the common value model, ${ }^{264}$ the successful bidder is the one who estimates the value of the item at the highest level. Because this bidder will have made an estimate that is higher than any other bidder, and because the bidders are acting without full information about the outcome of the litigation, the winning bidder will therefore face the risk of overpayment, or the "winner's curse" problem. ${ }^{265}$ The possibility of overpayment causes rational bidders to discount for that risk and can lead to inefficient, rather than competitive, prices. $^{266}$

259. See, e.g., Goldberger v. Integrated Resources, Inc., 209 F.3d 43, 55-56 (2d Cir. 2000) (upholding the trial court's refusal to apply a multiplier where counsel benefitted from information generated by parallel government investigations).

260. See id. at 49-50 (reaffirming the power of the district court to utilize either the lodestar or percentage-of-recovery method of calculating fees).

261. See John C. Coffee, Jr., "Auction Houses”: Legal Ethics and the Class Action, N.Y.L.J., May 18, 2000, at 5 (describing the dilemma faced by class counsel under a fee structure that fails to align counsel's incentives with those of the plaintiff class); Niebler, supra note 34, at 781 (arguing that low fee awards tend to cause lawyers to underfund class litigation).

262. See, e.g., Coffee, supra note 254 (citing examples of the incentives provided by particular bid structures for strategic behavior by defendants).

263. But see In re Cendant Corp. Litig., 191 F.R.D. 387, 390-91 (D.N.J. 2000) (rejecting several bids as unrealistically low).

264. See, e.g., R. Preston McAfee \& John McMillan, Auctions and Bidding, 25 J. EcON. LIT. 699, 720 (1987) (explaining common value auctions).

265. Id. at 720-21 (explaining winner's curse problem).

266. See id. at 721 (stating that a rational bidder may bid less to avoid becoming a victim of the winner's curse). 
Apart from the risk of overpayment, the preparation of a bid is costly. ${ }^{267} \mathrm{~A}$ bidding firm must investigate the case and predict the expected recovery under various litigation scenarios, as well as the cost associated with each possible recovery, to propose a rational bid structure. In the absence of careful investigation, a firm exposes itself to the risk that it will not cover its opportunity costs if it wins the auction. On the other hand, all costs of bid preparation are a deadweight loss if the firm is not the successful bidder. Accordingly, these costs may deter firms from bidding.

Lack of bidder participation is a serious risk in lead counsel auctions, because if firms do not bid, an auction will reduce rather than increase competition. In addition, limited bidder participation drastically reduces the likelihood that an auction will result in an efficient allocation of resources or an appropriate price. ${ }^{268}$ Several of the cases in which courts have used auctions suggest that the risk of limited bidder participation is real. For example, only four firms submitted bids in the Oracle auction, ${ }^{269}$ and Judge Walker had to conduct two rounds of bidding to obtain a total of three bids in Cylink..$^{270}$ The auction in In re California Micro Devices Securities Litigation ${ }^{271}$ resulted in only two bids, although seventeen firms had previously entered appearances representing members of the plaintiff class. ${ }^{272}$ Even the auction conducted in In re Amino Acid Lysine Antitrust Litigation resulted in the submission of only eight bids, despite the fact that approximately thirty-eight firms had entered an appearance prior to the court's decision to use an auction. ${ }^{273}$

The foregoing analysis does not demonstrate that it is impossible to construct a workable lead counsel auction. Nor does it reject the concerns about excessive fees, lack of competition, and lawyer control that have motivated courts to experiment with the auction process. Indeed, Congress created the lead plaintiff provision in an effort to address these same concerns. In the next section, this article demonstrates that the client empowerment model of the lead plaintiff provision is incompatible with and undermined by the lead counsel auction.

267. These costs are increased where the bidder has incomplete information about the market, as well as incomplete information about the value of the lead counsel position. Given the degree of variation in bids and bid structures, restrictions on disclosure of bid information reduce competition among bidders.

268. See McAfee \& McMillan, supra note 263, at 711, 721 (describing the efficiencies of the auction process under the assumption of perfect competition).

269. In re Oracle Sec. Litig., 132 F.R.D. 538, 539 (N.D. Cal. 1990).

270. Wenderhold v. Cylink Corp., 191 F.R.D. 600, 601 (N.D. Cal. 2000); Wenderhold v. Cylink Corp., 189 F.R.D. 570,572 (N.D. Cal. 1999).

271. 168 F.R.D. 257 (N.D. Cal. 1996).

272. See Sherleigh Assocs. v. Windmere-Durable Holdings, Inc., 184 F.R.D. 688, 700 n.2 (S.D. Fla. 1999) (describing the result of competitive bidding in California Micro Devices).

273. 918 F. Supp. 1190, 1190-92 (N.D. Ill. 1996). 


\section{Lead Counsel Auctions and the PSLRA}

Even if it were possible to design an appropriate auction model, there are serious reasons to question whether courts have authority under the PSLRA to employ an auction to select lead counsel. Although the Oracle decision predated the PSLRA, subsequent judicial use of lead counsel auctions has relied heavily on Oracle, ${ }^{274}$ and courts have devoted relatively little analysis to the effect of the lead plaintiff provision on their authority to select lead counsel. ${ }^{275}$

Courts employing auctions have relied on traditional judicial authority to select counsel and award counsel fees. The PSLRA does not eliminate this authority completely. Indeed, as indicated above, courts that have been faced with requests to appoint large consortia of lead counsel in post-PSLRA cases have been forced to determine the extent to which deference to the lead plaintiff's choice of counsel is appropriate. Moreover, the PSLRA retains an affirmative role for the court in counsel selection, by authorizing the court to approve or reject the lead plaintiff's choice. ${ }^{276}$ Citing the Conference Report on the statute, the courts in Milestone Scientific and Cendant explained that the lead plaintiff does not come inextricably tied to its counsel. ${ }^{277}$ Finally, the PSLRA contains no language removing fee awards from the court's authority. Once the authority to set counsel fees and to reject the lead plaintiff's choice of counsel is acknowledged, it seems but a small step to conclude that the court may use an auction process to select lead counsel and determine the fee award. The auction device appears no more problematic than the percentage-ofrecovery or lodestar methods of determining counsel fees, both of which are also creatures of judicial creation.

This conclusion, however, is inconsistent with the language of the PSLRA. The statutory text clearly vests the lead plaintiff, not the court, with the authority to select lead counsel. ${ }^{278}$ Although the court can exercise veto power over the lead plaintiff's selection, the statute provides no basis for the court to override the plaintiff's selection and to impose its choice of counsel or to presume that it exercises complete discretion with respect to such selection.

On the other hand, the statute does not describe the court's role when the plaintiff's choice of counsel is unacceptable. What are the consequences if the court determines that the lead plaintiff is incapable of selecting counsel, if the court rejects a proffered lead counsel consortium, or if the court rejects the lead

274. See, e.g., Sherleigh Assocs., 184 F.R.D. at 693. The court also relied heavily on the analysis of auction theory in Andrew Niebler's law review article. See id., citing Niebler, supra note 34.

275. See In re Lucent Techs. Sec. Litig., 194 F.R.D. 137, 156 (D.N.J. 2000) (justifying the auction procedure as "necessary to protect the interests of the proposed class" and limiting its analysis to citations of Cendant and Cylink decisions).

276. See CONF. REP., supra note 19, at 33-35 ("The Conference Committee does not intend to disturb the court's discretion under existing law to approve or disapprove the lead plaintiff's choice of counsel when necessary to protect the interests of the plaintiff class.").

277. See In re Milestone Scientific Sec. Litig., 187 F.R.D. 165, 176 (D.N.J. 1999); In re Cendant Corp. Litig., 182 F.R.D. 144, 149 (D.N.J. 1998).

278. See 15 U.S.C. $\$ 78 u-4(a)(3)(B)(v)$ (Supp. IV 1998). 
plaintiff's choice as unqualified? The statute fails to provide guidelines for the scope of judicial review of the lead plaintiff's selection. ${ }^{279}$ Nor does it explain what happens when a court exercises its veto power over the plaintiff's choice.

In the absence of textual guidance, it is appropriate to look again to the objectives of the statutory scheme. Importantly, the Oracle decision was predicated on the conclusion that no single class member had a sufficient stake to oversee the litigation and that, as a result, no one would "shop around" among the interested law firms to negotiate the best terms for representation. ${ }^{280}$ In adopting the PSLRA, Congress created an affirmative structure designed to change this result. ${ }^{281}$ Lead plaintiffs, particularly institutional investors, are armed with the statutory authority to select counsel and control litigation decisions and therefore have the power to introduce a competitive market process into securities litigation.

Lead plaintiff auctions interfere with the statutory objective of client empowerment by displacing the plaintiff's authority over counsel selection. The PSLRA empowers the lead plaintiff to monitor class counsel by (1) selecting appropriate counsel; (2) negotiating a fee structure that minimizes agency costs and creates appropriate incentives for lawyer decisionmaking; (3) negotiating a fee that reflects market forces; and (4) exercising continuing oversight throughout the course of the litigation. This monitoring can potentially reduce the excessive lawyer control targeted by the PSLRA.

Judicial selection of counsel, by an auction or otherwise, thwarts the lead plaintiff's ability to monitor the process. The plaintiff's efforts to select appropriate counsel and negotiate a fee agreement are undermined if the court is free to select another lawyer. The lead plaintiff cannot be expected to develop a close working relationship with a lawyer appointed by the court. Nor can the lead plaintiff be expected to monitor court-appointed counsel effectively, absent control over counsel's compensation in the case at bar and the potential for repeat business in comparable cases.

Moreover, the lead plaintiff structure is designed to select lead plaintiffs that are particularly well suited to monitor class counsel. As indicated above, for example, Congress expressed the desire to encourage institutional investors to serve as lead plaintiffs. ${ }^{22}$ Because of their substantial stakes, sophistication, and status as repeat players in securities litigation, institutions are particularly well

279. See, e.g., Laborers Local 1298 Pension Fund v. Campbell Soup Co., [2000 Transfer Binder] Fed. Sec. L. Rep. (CCH) II 90,963, at 94,222 (D.N.J. May 17, 2000) (directing lead plaintiffs to meet to discuss the appointment of class counsel and specifying a variety of criteria to be considered by the court in deciding whether to approve the plaintiffs' selection).

280. See Weiss \& Beckerman, supra note 16, at 2088-94 (describing this conclusion and refuting it with respect to securities class actions by demonstrating the prevalence of claimants with substantial stakes).

281. Moreover, Congress had the auction alternative available to it at the time that it adopted the PSLRA. Macey \& Miller's article on class action auctions, supra note 9, and the Oracle decision both predated the statute. See also Testimony of Arthur Miller, supra note 150, at 159 (identifying various shortcomings of the auction procedure to Congress).

282. See supra notes 151-154 and accompanying test. 
suited to monitor plaintiffs' counsel and to negotiate sophisticated compensation agreements that reduce legal fees and minimize agency costs. ${ }^{283}$ Even when the lead plaintiff is an individual investor rather than an institution, the lead plaintiff is likely to be an individual of substantial net worth, with business expertise and experience in dealing with lawyers, as well as a significant stake in the litigation. Such an investor is fully capable of selecting counsel.

With respect to the amount and structure of fee awards, the lead plaintiff provision is particularly promising. Weiss and Beckerman hoped that the lead plaintiff provision would enable institutions and other large investors to negotiate fee arrangements with class counsel ex ante, thereby causing fee awards in class actions to conform more closely to market rates. ${ }^{284}$ Institutional investors seemingly engage in precisely this type of negotiation. A number of institutional investors have claimed in public statements that they have negotiated fee agreements in shareholder litigation that are substantially below industry benchmarks. ${ }^{285}$

Judicial override of the lead plaintiff's decision will impede these developments and frustrate the statutory objectives. Auctions would likely deter institutional investors from seeking appointment as lead plaintiffs because of their reluctance to take on the responsibility of the lead plaintiff position without the ability to work with their choice of counsel. This is particularly true when an institutional investor has conducted an active search and negotiated a fee agreement. In Network Associates, ${ }^{286}$ for example, the Board of Pensions of the City of Philadelphia withdrew its application to serve as lead plaintiff after the court refused to accept its choice of counsel and instead ordered an auction. ${ }^{287}$

From a policy perspective, lead counsel auctions have several shortcomings. In addition to the practical issues presented by the auction structure, a selection process that disregards differences in the competing firms' early efforts creates undesirable incentives with respect to future litigation. The public interest is served by lawyers who carefully conduct investigations prior to filing a complaint. Indeed, the pleading standards of the PSLRA require such investigation for a complaint to withstand a motion to dismiss. Investigation, however, is costly, and a lawyer's investigatory efforts are penalized if they can be appropriated by a low-bidding latecomer. Under the auction model, the firms that perform work early in a case face a risk that they will not be compensated; ${ }^{288}$

283. See Weiss \& Beckerman, supra note 16, at 2121-23.

284. See id. at 2107.

285. See supra note 57.

286. 76 F. Supp. 2d 1017 (N.D. Cal. 1999).

287. See CA Judge Picks Lone Investor for Lead Plaintiff After Others Balk, PROF. LIAB. LITIG. REP. Jan. 17, 2000, at 8 (describing a Philadelphia retirement fund's refusal to proceed as lead plaintiff if required to conduct a sealed bid auction to select lead counsel).

288. Cf. In re Bank One Shareholders Class Actions, 96 F. Supp. 2d 780, 790 n.13 (N.D. Ill. 2000) (acknowledging that a rejected bidder had undertaken the responsibility of preparing the consolidated class action complaint and stating, without further specification as to the details, the court's expectation that the firm would be "fully compensated" for these services). 
firms that do no initial work preserve lower cost structures that give them an advantage in the auction. ${ }^{289}$

Finally, lead counsel auctions are based on an activist role for the court as monitor of the litigation and guardian for the plaintiff class. It is not clear that this role is either desirable or consistent with the PSLRA. There is no reason to believe that judicially conducted auctions will produce better prices or more appropriate fee structures than negotiations by lead plaintiffs. Selection of counsel is a business decision, and courts are poorly suited to make business decisions. ${ }^{290}$ Indeed, the fact that the Cendant auction resulted in a fee structure in which counsel received a higher award than counsel would have received under the privately negotiated fee agreement underscores this point. ${ }^{291}$

It is also fair to read the adoption of the PSLRA as reflecting some degree of congressional skepticism about the ability of the courts effectively to supervise the process of selecting class counsel. The legislative history of the PSLRA reflects congressional frustration over many attributes of the litigation system that developed under judicial oversight. ${ }^{292}$ For example, the judicially created first-to-file rule provided the incentives that produced the race to the courthouse. The absence of a notice requirement precluded competition among would-be lead plaintiffs and their counsel. The courts' refusal to evaluate carefully the credentials of the class representatives led to the disempowerment of the class representative and the consequent lawyer control over litigation decisions. Finally, judicial control over plaintiff's attorneys' fees, coupled with the courts' reluctance to refuse fee requests or to deviate from traditional benchmarks, has led to excessive fee awards. Although it is unfair to hold the courts responsible for all these problems, in many cases the courts' acceptance of questionable practices as well as judicially created incentives contributed to the potential for abuse. ${ }^{293}$

The court's activist role may create an additional set of agency problems. Although the agency costs created by the divergence of lawyer and class interests are well recognized, there is a less-recognized gap between the interests of the judge and the plaintiff class. The pressures imposed by limited resources and crowded dockets have caused courts to take a more managerial approach to

289. The auction also creates the possibility of wasted work effort, if the bidding process displaces a firm that has done substantial investigation. The court's choice of preauction procedures may exacerbate this problem. In Bank One, for example, because the court had not completed the auction when the defendant filed a motion to dismiss, the court required all the competing firms to respond to the motion. See In re Bank One Shareholders Class Actions, 2000 U.S. Dist. LEXIS 6027, at *4-5 (N.D. Ill. 2000). Nonetheless, the court's order did not provide that unsuccessful bidders would be compensated for their efforts in responding to the motion.

290. This fact is reflected, in corporate law, by the business judgment rule. See generally DENNIS J. BLOCK ET AL., THE BUSINESS JUDGMENT RULE 6-7 (4th ed. 1993).

291. See supra note 253 and accompanying text.

292. See supra Part II(A) (describing structure of class actions prior to the adoption of the PSLRA).

293. See, e.g., CONF. REP., supra note 19, at 33 (explaining how two judicially created incentives have driven the race to the courthouse: (1) courts have appointed counsel on a first-come, first-served basis without sufficient consideration of the quality of the complaint; and (2) courts have generally appointed the lead plaintiff based on the first filed complaint). 
judging. Where, as in class actions, judges have extensive power to dictate the litigation process and results, there is a risk that they will use this power in a manner that does not reflect the best interests of the plaintiff class. ${ }^{294}$

By casting the court as auctioneer and referee, lead counsel auctions also threaten the court's neutrality. First, as indicated above, in evaluating the auction bids, the court must form an opinion on the merits of the case and the predicted recovery. ${ }^{295}$ This opinion, formed without the benefit of discovery or any submission by the defendant, may influence the court's subsequent evaluation of a motion or a proposed settlement. Second, the court's selection of counsel, which includes a determination that counsel is qualified and has made a reasonable evaluation of the case, may create an unintentional bias that the defendant cannot overcome. Indeed, having conducted an auction, the court may be particularly unwilling to terminate the case in a manner that would preclude class counsel from recovering a reasonable fee. Third, judicial control over the selection of counsel makes counsel accountable to the court, not to the class. This control may allow institutional factors, such as judicial interest in docket control, to influence litigation decisionmaking.

The PSLRA responds to and displaces any justification for lead counsel auctions in securities litigation. Although lead counsel auctions offer a potential solution to concerns over excessive fees, lawyer control, and lack of judicially manageable standards for oversight, the PSLRA instead rejects the courtcentered auction solution in favor of empowering the lead plaintiff. The client empowerment structure of the PSLRA can be understood as a mechanism for reducing the supervisory role of the court. Because lead counsel auctions, by retaining judicial authority over the selection of class counsel, interfere with the lead plaintiff's role, they are inconsistent with the statutory structure.

\section{$\mathrm{V}$}

\section{CONCLUSION}

Application of the lead plaintiff provision of the PSLRA has resulted in the development of two disturbing trends, aggregation and auctions. The trends deal with facially separate issues: aggregation relates to the appointment of the lead plaintiff, and auctions address the selection of counsel. Nonetheless, they are disturbing for the same reasons. First, both aggregation and lead counsel auctions weaken the relationship between the lead plaintiff and class counsel and specifically reduce the ability of the lead plaintiff to exert control over litigation decisionmaking. Second, both trends lead to serious problems in implementing the lead plaintiff provision. Finally, the trends maintain an active judicial role in supervising the conduct of the litigation.

294. See Judith Resnick, Managerial Judging, 96 HARV. L. REV. 376 (1982) (describing the incentives that influence judges' managerial decisions).

295. See, e.g., In re Bank One Shareholders Class Actions, 96 F. Supp. 2d 780, 788 (N.D. Ill. 2000) (concluding that the claim was viable because it survived a motion to dismiss and estimating probable class recovery as within the " $\$ 4.6$ to $\$ 4.8$ billion range"). 
The problems described in this article should cause courts to think carefully about the effects of accepting either trend. Courts that use aggregation to appoint groups of unrelated investors as lead plaintiffs will continue to be involved in difficult questions of appropriate group size and composition. To the extent that courts defer to groups created by counsel, they are unfaithful to the objectives of the statute. Moreover, lead plaintiff groups are unlikely to function in accordance with the statutory design. In particular, there is little reason to believe that a lead plaintiff group can effectively select or monitor class counsel.

Selection of lead counsel by auction is not an attractive alternative. Lead counsel auctions present substantial issues in design and implementation. Moreover, the lead plaintiff provision itself eliminates the justification for an auction. There is little reason to believe that a judicially conducted auction can replicate the market process or result in a selection decision and fee award more appropriate than the decisions made by a suitable lead plaintiff.

Furthermore, both aggregation and auctions involve the court in a dangerous role. By increasing the court's involvement in the selection of the lead plaintiff and, in particular, the selection of class counsel, aggregation and auctions risk the court's neutrality. The effect of these trends is to enhance judicial empowerment at the expense of client control. In passing the PSLRA, Congress adopted precisely the opposite approach to litigation reform. 